\title{
31. STRONGLY DEPLETED THOLEITTES FROM THE ROCKALL PLATEAU MARGIN, NORTH ATLANTIC: GEOCHEMISTRY AND MINERALOGY ${ }^{1}$
}

\author{
J. L. Joron, Laboratoire P. Süe, Centre National pour l'Exploitation des Océans \\ H. Bougault, Centre Océanologique de Bretagne \\ R. C. Maury, Université de Bretagne Occidentale \\ M. Bohn, Centre Océanologique de Bretagne and Université de Bretagne Occidentale \\ and \\ A. Desprairies, Université de Paris-Sud ${ }^{2}$
}

\begin{abstract}
The Leg 81 basalts, drilled either from the margins ("dipping reflectors" sequence: Holes 552, 553A, and 554A) or from the "continental" side (Hole 555) of the Rockall Plateau microcontinent, are strongly light rare-earth element (LREE) depleted oceanic tholeiites. The basalts from the four holes are almost similar. Most of their primary characteristics have been preserved, although they have suffered alteration by seawater. From the petrological and mineralogical points of view, they resemble deep-ocean-floor basalts but show some peculiarities (occurrence of pigeonite and ilmenite as normal components of the groundmass differentiation sequences toward ferrobasalts). Their geochemical characteristics are dominated by their extreme depletion in the most hygromagmaphile elements $(\mathrm{Th}, \mathrm{Ta}, \mathrm{La}$, and $\mathrm{Nb}$ ), the concentrations of which are sometimes lower than the corresponding chondritic values. Leg 81 basalts are thus clearly different from continental tholeiites (flood basalts): Possible equivalents in the Thulean Tertiary Magmatic Province include the LREE-depleted tholeiites from the Upper Basaltic Series of the Faeroe Islands and the Preshal Mhor basalt type from the British Tertiary Province.
\end{abstract}

\section{INTRODUCTION}

The Rockall Plateau, a topographically isolated shallow area located in the North Atlantic (Fig. 1), represents a microcontinent with typically continental composition and structure (Roberts, 1970, 1971). The Deep Sea Drilling Project (DSDP) Leg 81 sites were located on its southwestern margin, in order to examine the sedimentary and magmatic events that have taken place on this continent-ocean boundary since the first rifting and spreading periods. One of the prominent characteristics of the Rockall Plateau margin is the occurrence of strong oceanward-dipping reflectors (down to $4 \mathrm{~km}$ sub-bottom depth), the basaltic nature of which has been proved by Leg 81 drillings. Basalts have been recovered from the bottom of four holes.

Hole 552 was drilled at a depth of $2311 \mathrm{~m}$ on the southwest margin of the Rockall Plateau, about $40 \mathrm{~km}$ southeast of the oldest identifiable magnetic anomaly (Anomaly 24B) recorded in the adjacent oceanic crust. Basalt, probably corresponding to the top of the dipping reflectors sequence, was encountered below early Eocene sediments from 282.65 to $290.60 \mathrm{~m}$ below the seafloor (BSF). A single sample of basalt (Sample 552$22-1,20-24 \mathrm{~cm}$ ) is available for this study.

Hole 553A was located $7.3 \mathrm{~km}$ southwest (oceanward) of Hole 552. About 30 basalt flows (Unit V) were drilled

\footnotetext{
${ }^{1}$ Roberts, D. G., Schnitker, D., et al., Init. Repts. DSDP, 81: Washington (U.S. Govt. Printing Office).

2 Addresses: (Joron) Laboratoire P. Sũe, CNRS-CEN Saclay, BP. 2, 91190 Gif-surYvette, France; (Bougault and Bohn) Centre Octanologique de Bretagne, CNEXO, BP. 337, 29273 Brest, France, and G.I.S. 410012; (Maury and Bohn) Université de Bretagne Occidentale, 29283 Brest, France, and G.I.S. 410012; (Desprairies) Université de Paris-Sud, Bât. 504, 91405 Orsay, France.
}

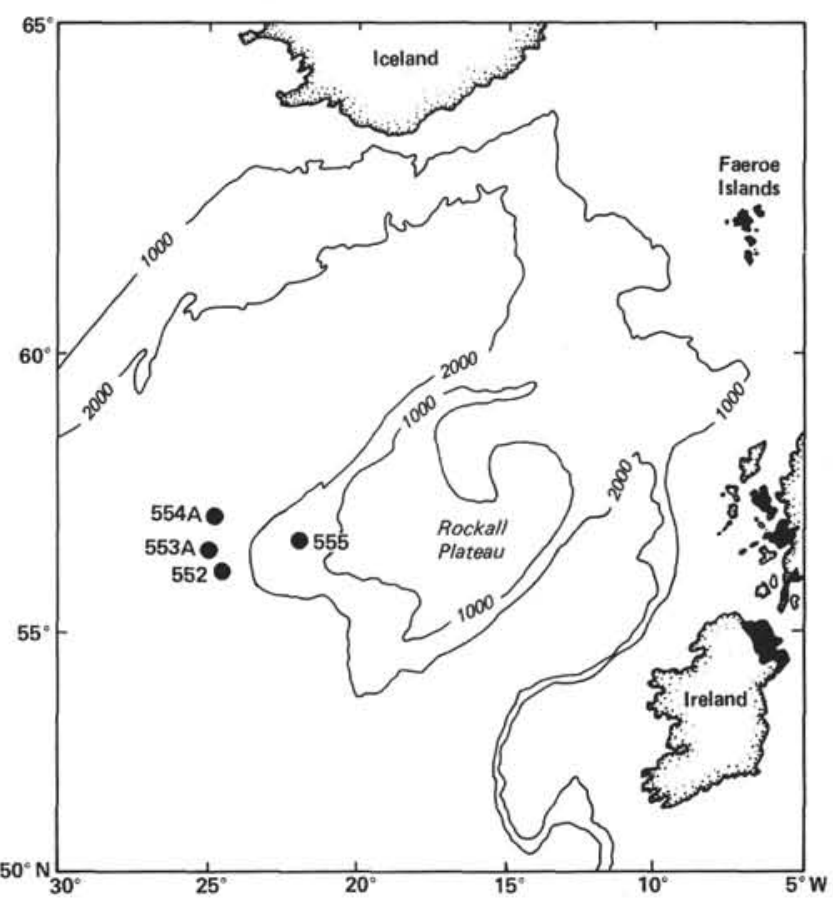

Figure 1. Location of Holes 552, 553A, 554A, and 555 on the SW margin of the Rockall Plateau. (1000- and 2000-m isobaths are shown. In black: Tertiary basalts from the Faeroe Islands and the Hebrideans Province.)

from 499.5 to $682.5 \mathrm{~m}$ BSF; they are overlain by early Eocene sediments, and late Paleocene ones are interbedded within the basaltic units. This hole provided a good opportunity to study the dipping reflectors sequence, the top of which was encountered at Hole 552. The ba- 
saltic sequence of Hole 553 $\mathrm{A}$ has been subdivided into three subunits (Subunits Va, Vb, Vc) from the physical and magnetic properties data and the downhole logs.

Hole 554A was drilled on the extreme west margin of the Rockall Plateau (Fig. 1), on the "outer high" separating the zone of the dipping reflectors from the adjacent oceanic crust (Anomaly 24B). Six submarine basalt flows were cored at the bottom of the hole, from 126.75 to $209 \mathrm{~m}$ BSF.

Hole 555 was located on the "continental" side of the Leg 81 transect (Fig. 1), between Hatton Bank and Edoras Bank, some $160 \mathrm{~km}$ ENE of Hole 554A. Basalts interbedded with vitric sandy mudstones, sandstones, and volcanic breccias were cored from 672.3 to $964 \mathrm{~m}$ BSF. Eleven emplacement units were distinguished: they are either single, relatively thick flow units or single or composite pillow lava units. Associated sediments are of late Paleocene age.

Geochemical (major and trace elements) and mineralogical (microprobe) studies have been conducted on 32 samples from Leg 81 sites (Hole 552: 1 sample; Hole 553A: 15 samples; Hole 554A: 3 samples; Hole 555: 13 samples), with two major goals:

1. Characterization of the basaltic "dipping reflectors" materials;

2. Comparison with North Atlantic ocean crust basalts as well as with presumably similar Paleocene to early Eocene basaltic sequences exposed in the Faeroe Islands, in East Greenland, and in the Hebrideans Tertiary Basaltic Province (Fig. 1).

\section{LITHOLOGY}

The Leg 81 basalts show few textural variations, and the 32 samples studied can be classified into three textural types:

1. Subaphyric or sparsely phyric basalts, containing some millimetric zoned plagioclase phenocrysts, occasionally joined by augite and/or altered olivine phenocrysts, set in a fine-grained microlitic to subophitic groundmass with well-preserved plagioclase laths, clinopyroxene and titanomagnetite grains, altered olivine crystals and sometimes ilmenite. Samples belonging to this textural type come from Hole 552, from the top (Sections $40-1$ to $46-3$ ) and the bottom (Sections 50-2 to 59-4) of Hole 553A, and occasionally from Hole 555 (Sections 68-3, 82-1, and 93-2).

2. Phyric basalts showing glomeroporphyric aggregates of plagioclase, augite, and altered olivine in a finegrained microlitic groundmass similar to that previously described. Such samples have been found in the medium part of Hole 553A (Sections 47-3 to 49-3), in Hole 554A, and at the top of Hole 555 (Sections 69-4 and 70-1).

3. Ophitic or subophitic coarse-grained basalts, in which the primary mineral paragenesis (plagioclase + clinopyroxene + olivine + titanomagnetite + ilmenite) is well preserved, and in which fresh olivine crystals are sometimes found. The occurrence of this textural type seems to be restricted to the medium part and the bottom of Hole 555 (Sections 76-1 to 81-1, 83-1 to 90-3, and 96-2 to $97-1$ ).
Secondary minerals and products developed at the expense of the interstitial glass or filling vesicles and veins have been studied separately (see Desprairies et al., this volume): they include saponite, chabazite, and analcite (Hole 552); saponite and celadonite (Hole 553A); palagonite, saponite, and celadonite (Hole 554A); saponite, chlorite, albite, and analcite (Hole 555); together with calcite and quartz.

\section{MAJOR-ELEMENT COMPOSITIONS}

The 32 analyses given in Table 1 are typically basaltic, although the three samples from Subunit Va of Hole 553A (Samples 553A-40-1, 82-85 cm; 553A-43-2, 37-42 $\mathrm{cm}$; $553 \mathrm{~A}-44-2,51-55 \mathrm{~cm})$ are slightly more evolved than the others $\left(\mathrm{SiO}_{2}\right.$ up to $\left.53.2 \%\right)$ and transitional toward ferrobasalts. Leg 81 basalts are actually tholeiitic in character, quartz tholeiites (26 samples) dominating over olivine tholeiites (5 samples); the single nephelinenormative basalt (Sample 555-93-2, 144-146 cm) is also the most altered one, as indicated by its high loss-on-ignition (LOI) value (3.5\%). The major-element compositions do not depart in any way from those of typical oceanic tholeiites, and no important variation between the four holes can be detected. The $\mathrm{K}_{2} \mathrm{O}$ contents are extremely low, as in most fresh ocean-floor basalts, and they exceed $0.2 \%$ only in samples with high LOI values (more than 1.5\%). These altered samples (e.g., Samples 552-22-1, 20-24 cm; 553-81-1, 110-115 cm; 555-93-2, $144-146 \mathrm{~cm}$ ) are more accessorily enriched in $\mathrm{MgO}$ and somewhat depleted in $\mathrm{SiO}_{2}$ and $\mathrm{CaO}$ in accordance with the classical chemical trends in major elements noted during basalt-seawater interactions (Donnelly et al., 1979).

The two thick basaltic sequences drilled in Holes 553A and 555 are not strictly similar to one another: Hole 555 basalts do not show noticeable systematic variations correlated with their stratigraphic position, although clear differences appear between basaltic Subunits $\mathrm{Va}, \mathrm{Vb}$, and $\mathrm{Vc}$ of Hole 553A (Fig. 2). In this latter sequence, solidification index (SI) values range from 42 to 25 , and the uppermost basalts (Subunit Va) are the most evolved, the lowest ones (Subunit Vc) being the most primitive. Primary systematic variations of this kind are relatively infrequent in DSDP basaltic sequences: They allow a magmatic series to be defined in Hole 553A, the evolution of which (Fig. 2) is typically tholeiitic, with progressive increase in $\mathrm{SiO}_{2}, \mathrm{TiO}_{2}$, total iron, and $\mathrm{Na}_{2} \mathrm{O}$ and corresponding decrease in $\mathrm{MgO}$ and $\mathrm{CaO}$.

\section{PRIMARY MINERALS}

\section{Olivine}

Fresh olivine occurs only in the ophitic samples from the bottom of Hole 555, as small phenocrysts $(<200$ $\mu \mathrm{m})$ and interstitial crystals. Olivine analyses from Sample 555-97-1, 34-38 cm are given in Table 2: they show fayalite contents of 37-58 mol \%, which appear surprisingly high owing to the Mg-rich character of the host rock $(\mathrm{MgO}=7.77 \%$; $\mathrm{SI}=36.58)$. Such iron-rich olivine compositions are typical of tholeiitic or transitional series (Bizouard et al., 1980), but their occurrence in a 
Table 1. Major element analyses of basalts from Holes 552, 553A, 554A, and 555.

\begin{tabular}{|c|c|c|c|c|c|c|c|c|c|c|c|c|c|c|c|c|c|c|c|c|c|c|c|c|c|}
\hline \multirow{2}{*}{$\begin{array}{c}\text { Sample } \\
\text { (interval in cm) }\end{array}$} & \multirow{2}{*}{$\begin{array}{r}\mathrm{Sc} \\
\mathrm{NA}\end{array}$} & \multirow{2}{*}{$\begin{array}{c}\mathrm{Ti} \\
\mathrm{XRF}\end{array}$} & \multirow{2}{*}{$\begin{array}{c}\mathrm{V} \\
\mathrm{XRF}\end{array}$} & \multirow{2}{*}{$\begin{array}{c}\mathrm{Cr} \\
\mathrm{XRF}\end{array}$} & \multirow{2}{*}{$\begin{array}{l}\mathrm{Mn} \\
\mathrm{XRF}\end{array}$} & \multirow{2}{*}{$\begin{array}{c}\mathrm{Fe} \\
\mathrm{XRF}\end{array}$} & \multicolumn{2}{|c|}{ Co } & \multicolumn{2}{|c|}{$\mathrm{Ni}$} & \multirow{2}{*}{$\begin{array}{c}\mathrm{Zn} \\
\mathrm{XRF}\end{array}$} & \multirow{2}{*}{$\begin{array}{c}\mathrm{Rb} \\
\mathrm{XRF}\end{array}$} & \multirow{2}{*}{$\begin{array}{c}\mathrm{Sr} \\
\mathrm{XRF}\end{array}$} & \multirow{2}{*}{$\underset{\mathrm{XRF}}{\mathrm{Y}}$} & \multirow{2}{*}{$\begin{array}{c}\mathrm{Zr} \\
\mathrm{XRF}\end{array}$} & \multirow{2}{*}{$\begin{array}{l}\mathrm{Nb} \\
\mathrm{XRF}\end{array}$} & \multirow{2}{*}{$\begin{array}{l}\mathrm{Cs} \\
\mathrm{NA}\end{array}$} & \multirow{2}{*}{$\begin{array}{r}\text { La } \\
\text { NA }\end{array}$} & \multirow{2}{*}{$\begin{array}{l}\mathrm{Ce} \\
\mathrm{NA}\end{array}$} & \multirow{2}{*}{$\begin{array}{l}\text { Eu } \\
\text { NA }\end{array}$} & $\mathrm{Tb}$ & $\mathrm{Hf}$ & $\mathrm{Ta}$ & Th & $\mathrm{U}$ \\
\hline & & & & & & & XRF & NA & XRF & NA & & & & & & & & & & & NA & NA & NA & NA & NA \\
\hline $552-22-1,20-24$ & 52.4 & 21780 & 574 & 165 & 929 & 129500 & 46 & 47 & 44 & 54 & 115 & 0 & 130 & 78.0 & 206 & 6.6 & & 6.00 & 16.2 & 2.66 & 1.71 & 6.06 & 0.310 & 0.310 & 0.07 \\
\hline $553 \mathrm{~A}-40-1,82-85$ & 42.7 & 8400 & 321 & 55 & 1703 & 97020 & 48 & 47 & 44 & 49 & 99 & 0.7 & 76 & 45.9 & 112 & 1.3 & & 2.20 & 7.7 & 1.29 & 0.88 & 3.22 & 0.075 & 0.092 & \\
\hline $553 \mathrm{~A}-43-2,37-43$ & 48.7 & 9420 & 439 & 98 & 1316 & 108430 & 54 & 52 & 51 & 58 & 112 & 1.3 & 79 & 48.4 & 109 & 2.2 & & 2.00 & 10.8 & 1.39 & 0.96 & 3.01 & 0.076 & 0.088 & \\
\hline $553 \mathrm{~A}-44-2,51-55$ & 46.2 & 8820 & 400 & 88 & 1858 & 104860 & 57 & 52 & 57 & 62 & 107 & 0.4 & 75 & 47.5 & 97 & 2.8 & & 1.68 & 4.7 & 1.15 & 0.87 & 2.76 & 0.059 & 0.071 & \\
\hline $553 \mathrm{~A}-46-2,99-103$ & 47.2 & 6960 & 391 & 78 & 2167 & 100380 & 55 & 55 & 70 & 78 & 89 & 0.3 & 73 & 31.4 & 61 & 1.1 & & 0.81 & 4.8 & 0.97 & 0.63 & 1.62 & 0.035 & 0.017 & \\
\hline $553 \mathrm{~A}-46-3,141-145$ & 47.5 & 6900 & 374 & 81 & 2012 & 100730 & 55 & 55 & 71 & 78 & 85 & 0 & 72 & 31.1 & 61 & 1.9 & & 1.06 & 4.2 & 0.95 & 0.60 & 1.67 & 0.040 & 0.034 & \\
\hline $553 \mathrm{~A}-47-3,16-19$ & 48.5 & 9000 & 405 & 90 & 1780 & 110530 & 60 & 57 & 67 & 72 & 92 & 0 & 80 & 38.8 & 79 & 1.0 & & 0.88 & 4.9 & 1.20 & 0.79 & 2.26 & 0.065 & 0.058 & \\
\hline $553 \mathrm{~A}-48-4,68-71$ & 47.1 & 8520 & 439 & 143 & 2400 & 107100 & 57 & 55 & 76 & 82 & 101 & 0 & 75 & 39.9 & 81 & 2.2 & & 1.30 & 4.5 & 1.07 & 0.75 & 2.13 & 0.060 & 0.050 & \\
\hline $553 \mathrm{~A}-49-3,81-84$ & 47.2 & 8520 & 407 & 140 & 1780 & 109270 & 58 & 56 & 72 & 84 & 96 & 0 & 73 & 38.8 & 80 & 2.2 & & 1.30 & 5.9 & 1.19 & 0.80 & 2.25 & 0.060 & 0.038 & \\
\hline $553 \mathrm{~A}-50-2,89-93$ & 46.9 & 5880 & 354 & 170 & 2012 & 89040 & 53 & 52 & 87 & 94 & 74 & 0 & 63 & 28.9 & 69 & 1.3 & & 0.72 & & 0.76 & 0.53 & 1.39 & 0.026 & 0.019 & \\
\hline $553 \mathrm{~A}-51-2,99-102$ & 46.8 & 6300 & 370 & 136 & 2167 & 92540 & 54 & 54 & 79 & 87 & 86 & 0 & 72 & 29.9 & 52 & 2.8 & & 0.81 & & 0.83 & 0.57 & 1.34 & 0.025 & 0.045 & \\
\hline $553 \mathrm{~A}-52-2,47-50$ & 48.4 & 6480 & 375 & 137 & 7740 & 87850 & 52 & 53 & 83 & 86 & 70 & 0.9 & 75 & 30.6 & 55 & 1.2 & & 0.80 & 3.9 & 0.88 & 0.59 & 1.44 & 0.032 & 0.022 & \\
\hline $553 \mathrm{~A}-54-4,51-54$ & 54.2 & 9120 & 489 & 85 & 2245 & 98560 & 60 & 58 & 64 & 64 & 115 & 0.3 & 86 & 35.5 & 81 & 0.6 & & 1.09 & 3.7 & 1.20 & 0.73 & 2.10 & 0.039 & 0.044 & \\
\hline $3 \mathrm{~A}-55-5,14-17$ & 45.3 & 6060 & 369 & 121 & 2012 & 101990 & 60 & 61 & 74 & 83 & 78 & 0 & 69 & 29. & 57 & 2.0 & & 0.91 & 3.1 & 0.86 & 0.59 & 1.39 & 0.030 & 0.016 & \\
\hline $553 \mathrm{~A}-58-2,78-81$ & 47.2 & 6000 & 369 & 352 & 1780 & 76580 & 47 & 46 & 103 & 107 & 74 & 0 & 78 & 23.5 & 55 & 1.4 & & 0.54 & & 0.76 & 0.48 & 1.42 & 0.032 & 0.035 & \\
\hline $553 \mathrm{~A}-59-4,71-75$ & 44.2 & 5820 & 331 & 302 & 2167 & 88690 & 50 & 51 & 102 & 111 & 74 & 0 & 65 & 27.1 & 55 & 1.8 & & & 2.0 & 0.78 & 0.53 & 1.42 & 0.029 & 0.038 & \\
\hline $554 \mathrm{~A}-7-2,66-69$ & 49.1 & 6240 & 368 & 59 & 1625 & 102970 & 52 & 52 & 56 & 61 & 85 & 8.4 & 81 & 28. & 55 & 2.3 & 0.15 & 1.18 & 3.4 & 0.92 & 0.55 & 1.48 & 0.053 & 0.095 & 0.12 \\
\hline $4 A-7-4,82-85$ & 48.7 & 6360 & 374 & 56 & 1625 & 94360 & 55 & 56 & 58 & 6 & 91 & 2.3 & 8 & & 58 & & 0.07 & & 4.8 & & & & & 0.087 & \\
\hline $554 \mathrm{~A}-14-1,68-77$ & 45.8 & 6780 & 382 & 254 & 1393 & 92540 & 52 & 52 & 77 & 80 & 91 & 4.1 & 83 & 28.8 & 69 & 1.6 & 0.22 & 1.37 & 5.4 & 0.87 & 0.57 & 1.71 & 0.065 & 0.091 & \\
\hline $555-68-3,108-111$ & 48.1 & 10380 & 429 & 196 & 2245 & 93030 & 46 & 45 & 85 & 89 & 93 & 0 & 108 & 43. & 103 & 1.6 & & 2.5 & 9.1 & 1.39 & 0.91 & 2.86 & 0.089 & 0.187 & 0.05 \\
\hline $555-69-4,88-92$ & 48.2 & 10200 & 409 & 179 & 2399 & 96180 & 47 & 47 & 84 & 94 & 88 & 0.8 & 107 & 44.3 & 104 & 2.9 & & 2.57 & 9.8 & 1.54 & 0.93 & 2.95 & 0.100 & 0.160 & \\
\hline $555-70-1,112-117$ & 49.4 & 6540 & 353 & 177 & 2245 & 76580 & 51 & 55 & 83 & 93 & 80 & 0 & 10 & 27.1 & 60 & 2.0 & & 1.40 & 3.5 & 0.96 & 0.58 & 1.62 & 0.040 & 0.071 & \\
\hline $555-76-1,117-121$ & 50.7 & 6300 & 324 & 300 & 2399 & 81620 & 52 & 54 & 85 & 89 & 76 & 0 & 8 & 31 & 57 & 1.0 & & 1.13 & 3.3 & 0.95 & 0.62 & 1.46 & 0.030 & 0.064 & \\
\hline $5-81-1,110-115$ & 44.1 & 6900 & 330 & 88 & 2245 & 88629 & 47 & 47 & 59 & 64 & 69 & 5.2 & 10 & 33. & 63 & 1.7 & 0.10 & 1.46 & 2.8 & 1.02 & 0.65 & 1.76 & 0.047 & 0.150 & \\
\hline $555-82-1,76-79$ & 54.6 & 8520 & 426 & 111 & 2245 & 93520 & 54 & 52 & 61 & & 58 & 0.5 & 105 & & 76 & 2.0 & & 2.80 & 8.1 & 1.28 & 0.80 & 2.23 & 0.057 & 0.190 & 0.04 \\
\hline $555-83-1,75-80$ & 49.4 & 7620 & 402 & 131 & 1548 & 96530 & 53 & 53 & 71 & 80 & 57 & 3. & 98 & 34.9 & 63 & 2.5 & & 1.62 & 4.0 & 1.09 & 0.71 & 1.68 & 0.055 & 0.016 & \\
\hline $555-90-2,109-112$ & 48.6 & 7860 & 388 & 81 & 1703 & 100100 & 54 & 53 & 55 & 60 & 78 & 0. & 92 & 36 & 66 & 1.6 & 0.05 & 1.60 & & 1.07 & 0.73 & 1.87 & 0.049 & 0.150 & 0.05 \\
\hline $555-90-3,54-57$ & 47.9 & 7740 & 315 & 74 & 1858 & 100170 & 49 & 49 & 58 & 61 & 87 & 0. & 91 & 44. & 88 & 1.7 & 0.04 & 2.00 & 5.1 & 1.36 & 0.88 & 2.48 & 0.077 & 0.210 & \\
\hline $555-93-2,144-146$ & 51.8 & 7800 & 447 & 194 & 2245 & & 52 & 49 & 69 & 71 & 153 & 3.5 & 114 & 34. & 72 & 1.4 & & 4.15 & 12.1 & 1. & 0.82 & 1.83 & 0.069 & 0.013 & \\
\hline $555-96-2,42-45$ & 47.9 & 6720 & 328 & 296 & 1703 & 92610 & 49 & 50 & 80 & 83 & 88 & 1.7 & 78 & 33 & 56 & 1.9 & 0. & 1.18 & 5.1 & 0.97 & 0.66 & 1.69 & 0.036 & 0.082 & \\
\hline $555-97-1,34-38$ & 49.3 & 6240 & 320 & 304 & 1625 & 90090 & 49 & 51 & 84 & 90 & 81 & 0.7 & 79 & 31.3 & 59 & 0.3 & 0.10 & 1.03 & 5.5 & 0.92 & 0.62 & 1.52 & 0.033 & 0.083 & \\
\hline $555-98-3,79-82$ & 49.2 & 6060 & 316 & 380 & 1548 & 87101 & 48 & 51 & 87 & 95 & 63 & 1.0 & 76 & 29.9 & 51 & 1.5 & 0.12 & 0.99 & 5.6 & 0.91 & 0.61 & 1.52 & 0.044 & 0.084 & \\
\hline
\end{tabular}

Note: $\mathrm{XRF}=\mathrm{X}$-ray fluoresence analyses, $\mathrm{NA}=$ neutron activation analyses. 


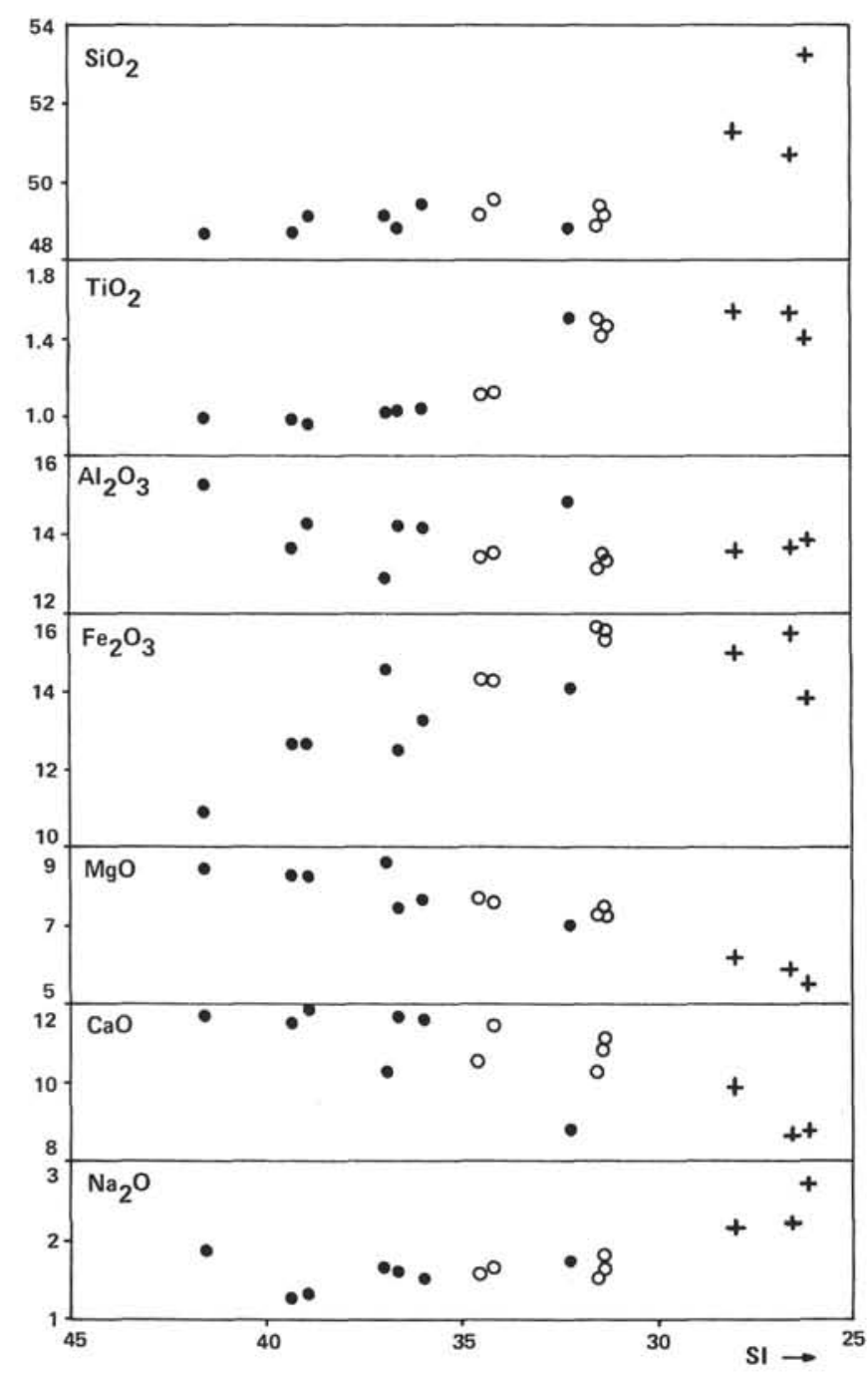

Figure 2. Oxide versus SI variation diagrams for volcanic rocks from Hole 553A. (Crosses $=$ samples from Subunit Va, open circles $=$ samples from Subunit $\mathrm{Vb}$, filled circles $=$ samples from Subunit Vc.)

Table 2. Olivine analyses.

\begin{tabular}{|c|c|c|c|c|c|c|c|}
\hline \multirow{3}{*}{$\begin{array}{l}\text { Position } \\
\text { Analysis }\end{array}$} & \multicolumn{7}{|c|}{$\begin{array}{c}\text { Sample } \\
555-97-1,34-38 \mathrm{~cm}\end{array}$} \\
\hline & $\mathrm{C}$ & $\mathrm{R}$ & C & $\mathrm{R}$ & G & G & G \\
\hline & 1 & 2 & 3 & 4 & 5 & 6 & 7 \\
\hline \multicolumn{8}{|c|}{ Major element oxide (wt.\%) } \\
\hline $\mathrm{SiO}_{2}$ & 36.47 & 35.87 & 36.17 & 36.65 & 35.26 & 35.04 & 34.44 \\
\hline $\mathrm{FeO}^{* \mathrm{a}}$ & 43.78 & 34.20 & 32.49 & 32.42 & 37.59 & 41.45 & 45.71 \\
\hline $\mathrm{MgO}$ & 18.22 & 29.60 & 31.44 & 31.28 & 25.92 & 22.24 & 19.83 \\
\hline $\mathrm{MnO}$ & 0.59 & 0.58 & 0.48 & 0.47 & 0.69 & 0.58 & 0.61 \\
\hline $\mathrm{CaO}$ & 0.30 & 0.22 & 0.33 & 0.31 & 0.33 & 0.30 & 0.28 \\
\hline Total & 99.36 & 100.47 & 100.91 & 101.13 & 99.79 & 99.61 & 100.87 \\
\hline $\mathrm{Fa}(\%)$ & 57.7 & 39.7 & 37.0 & 37.1 & 45.3 & 51.5 & 56.7 \\
\hline
\end{tabular}

Note: $\mathrm{C}=$ core of a phenocryst, $\mathrm{R}=$ rim of a phenocryst, $\mathrm{G}=$ groundmass crystal. All the microprobe analyses discussed in this paper (Tables 2-5) have been obtained with a Camebax-type automated microprobe (Microsonde Ovest, Brest; working conditions $15 \mathrm{kV}, 10 \mathrm{nA}$, counting time $=6 \mathrm{~s}$ ). Concentrations lower than $0.3 \%$ are not considered representative.

${ }^{\mathrm{a}} \mathrm{FeO}^{*}=$ total iron as $\mathrm{FeO}$. truly basaltic sample can only be explained by a relatively late appearance of olivine in the crystallization sequence of their host rock: following Leeman and Scheidegger's (1977) relationship, the two cores of pheoncrysts analyzed (Analyses 1 and 3, Table 2) should have been equilibrated for $\mathrm{Mg}$ and $\mathrm{Fe}$ with their whole rock at temperatures varying from 1110 to $1040^{\circ} \mathrm{C}$. The interstitial olivines are usually iron-enriched with respect to the phenocrysts, with the noticeable exception of Analysis 1 (Fe-rich core). The Mn contents increase along with the iron contents; $\mathrm{Ca}$ amounts are low and compatible with low-pressure crystallization (Stormer, 1973).

\section{Pyroxenes}

The prominent pyroxene phase in most samples is groundmass augite (Fig. 3 and Table 3), but calcic clinopyroxene phenocrysts occur sporadically in Leg 81 basalts: their cores are iron poor and plot near the endiopside-augite boundary in the $\mathrm{Ca}-\mathrm{Mg}-(\mathrm{Fe}+\mathrm{Mn})$ diagrams (Fig. 3). The compositions of their extreme rims and those of groundmass calcic clinopyroxenes show a considerable scatter in Figure 3 diagrams: they follow an iron-enrichment trend toward ferroaugitic compositions, which is typical of tholeiitic series, the most ironrich compositions (about $50 \mathrm{~mol} \%$ ferrosilite: Analyses 24 and 27, Table 3) corresponding to interstitial crystals from Hole-555 ophitic samples.

Some calcic clinopyroxene phenocrysts from Leg 81 basalts show strong chemical core-to-rim variations, exemplified in Figure 4. The prominent substitution corresponds to the increase of iron at the expense of $\mathrm{Ca}$ and $\mathrm{Mg}$, the $\mathrm{Mn}$ and $\mathrm{Ti}$ contents remaining approximately constant. The $\mathrm{Al}$ patterns are complex: the decrease of $\mathrm{Al}^{\mathrm{VI}}$ in the internal part of the crystal may be attributed to crystallization under decreasing pressures, although the abrupt variations of $\mathrm{Al}^{\mathrm{IV}}$ and the increase of $\mathrm{Al}^{\mathrm{VI}}$ in the external part would perhaps indicate changes in cooling rates (Coish and Taylor, 1979; Gamble and Taylor, $1980)$ presumably connected with the emplacement process.

A specific feature of Leg 81 basalts when compared to most of oceanic tholeiites lies in the common occurrence of Ca-poor pigeonitic clinopyroxenes (Fig. 3; Analyses $8,11,15,18,32,33,34$, Table 3). Although they have already been found in ocean-floor basalts as the result of extreme $\mathrm{Ca}$ depletion of augite resulting from quench trends (e.g., in Leg 49 basalts; Wood et al., 1979), Figure 3 shows that, with the possible exception of Hole 554A, there is no continuous transition from augite or ferroaugite to pigeonite or ferropigeonite through subcalcic augite or ferroaugite compositions [contrast with Wood et al.'s (1979) figure 47]. Moreover, pigeonite occurs in Leg 81 basalts either as independent microlites (Analyses 8, 9, 15, 18, Table 3), or as rims coating augitic cores (Analysis 32), or even as independent phenocrysts up to $200 \mu \mathrm{m}$ wide (Analyses 33-34) showing a noticeable iron enrichment from their core to their rim $\left(\mathrm{Fs}_{43}\right.$ to $\left.\mathrm{Fs}_{56}\right)$. Pigeonitic clinopyroxenes can thus be considered "normal" components of Leg 81 basalts. They have already been found to occur in other Thulean 

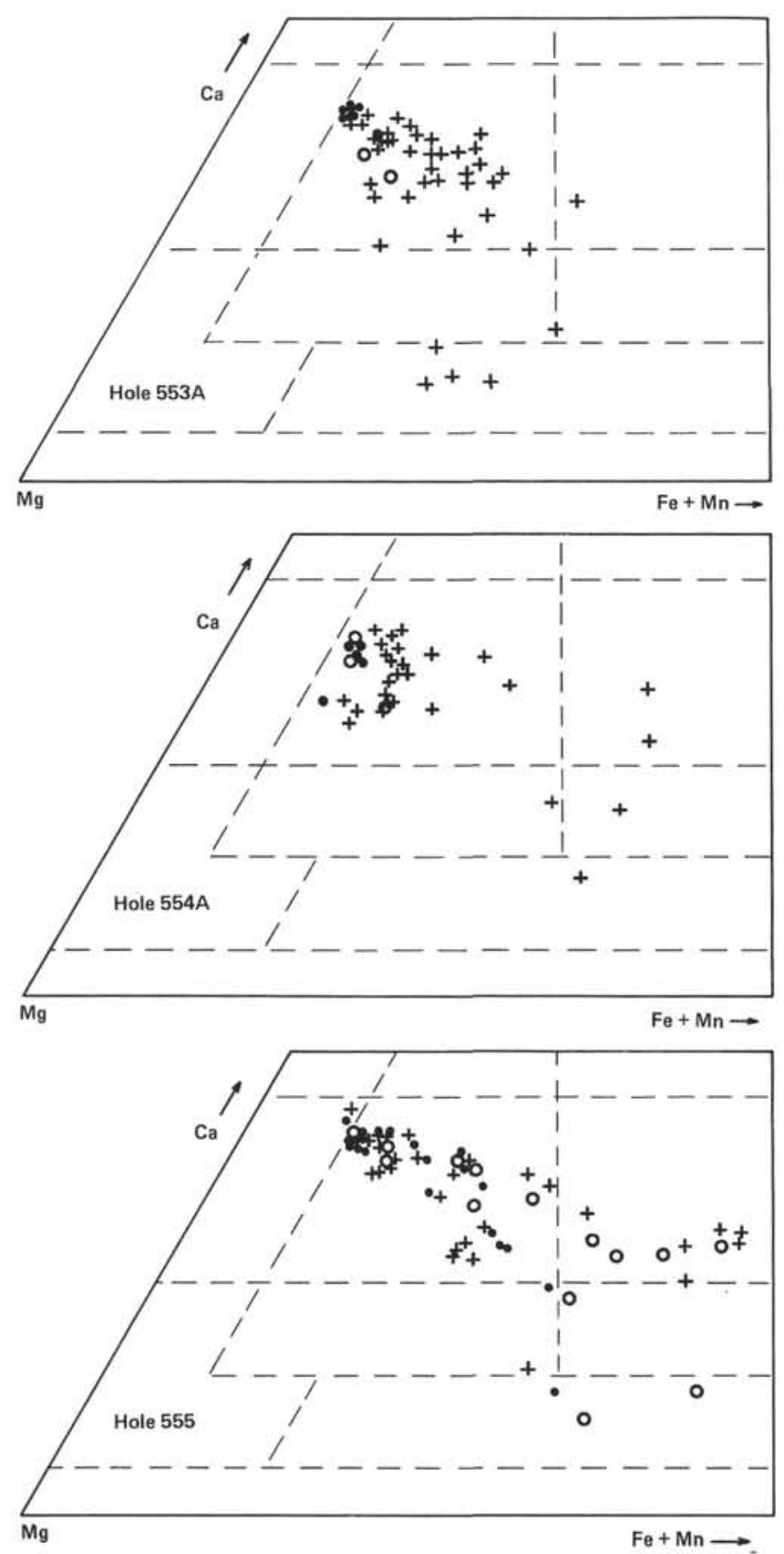

Figure 3. Clinopyroxene compositions plotted on $\mathrm{Ca}-\mathrm{Mg}-(\mathrm{Fe}+\mathrm{Mn})$ diagrams. (Filled circles $=$ cores of phenocrysts, open circles $=$ rims of phenocrysts, crosses = groundmass pyroxenes.)

basalts, especially from the Middle and Upper Basalts Series of the Faeroe Islands (Noe-Nygaard and Rasmussen, 1968; Jensen, 1978) and from the Antrim Plateau basalts, Northern Ireland (quoted by Preston, 1982).

\section{Iron-Titanium Oxides}

Titanomagnetite is very common in groundmass of Leg- 81 basalts, where it is often associated with hemoilmenite crystals, but in most cases it has been oxidized to magnemite. Some analyses of fresh or moderately oxidized coexisting iron-titanium oxides are given in Table 4; the corresponding $\mathrm{T}-\mathrm{fO}_{2}$ equilibration condi- tions, following Powell and Powell's (1977) formulation of Buddington and Lindsley's (1964) geothermometer, have been plotted in Figure 5. Oxides from Hole 553A basalts yield "reasonable" magmatic equilibration temperatures $\left(1200-1000^{\circ} \mathrm{C}\right)$, although those from a subophitic sample from Hole 555 indicate lower temperatures $\left(1000-700^{\circ} \mathrm{C}\right)$, probably corresponding to subsolidus re-equilibrations. The corresponding oxygen fugacities decrease with temperature with respect to the nickel-nickel oxide and fayalite-magnetite-quartz buffers (Fig. 5).

\section{Feldspars}

The compositions of the cores of the millimetric plagioclase phenocrysts widespread in Leg 81 basalts vary from $\mathrm{An}_{85}$ to $\mathrm{An}_{50}$, and these crystals are predominantly normally zoned. Their compositional variations are shown in Figure 6: there is a very rough positive correlation between the normative and the modal plagioclase compositions, the plagioclase cores from the most evolved basalts (Subunit Va of Hole 553A) being more sodic than the other ones. Figure 6 shows also that the plagioclases from the quickly cooled lava units (Holes 552, 553A, and 554A) are scarcely zoned (compositional variations being usually less than $5 \%$ anorthite), in contrast to the slowly cooled plagioclases from the ophitic or subophitic basalts from the bottom of Hole 555, which show important compositional variations reaching up to $30 \%$ anorthite (Analyses 51-56, Table 5). The compositions of the groundmass plagioclases and those of the extreme rims of phenocrysts range from $A_{n}$ and $A_{35}$, the most common ones being $\mathrm{An}_{70-60}$; again the most sodic groundmass plagioclases are found in well-crystallized samples. Some secondary interstitial alkali feldspars have been found in samples from the bottom of Hole 555 (Analysis 60, Table 5).

\section{TRACE-ELEMENT COMPOSITIONS}

The trace-element compositions of basalts from Holes $552,553 \mathrm{~A}, 554 \mathrm{~A}$, and 555 are given in Table 6 , where the elements have been presented in the order of increasing atomic number. All the measurements were made either by X-ray fluorescence spectrometry (XRF) at Centre Océanologique de Bretagne (Bougault et al. 1977; Bougault, 1980) or by instrumental neutron activation (INA) at P. Süe Laboratory (Chayla et al., 1973). For neutronactivation analysis, two international rock standards were used. Three samples of standard GS-N (De La Roche and Govindaraju, 1976) and one sample of another standard, BE-N, used as control, (Govindaraju, 1980) are placed in each irradiated samples container. The trace-element concentrations of the GS-N standard are reported in Table 7 , together with the values obtained for BCR-I and BE-N standards using GS-N reference concentrations. The accuracy of the method is about $5 \%$ for each trace element analyzed (Jaffrezic et al., 1980).

Table 6 data show that concentrations of trace elements in Leg 81 samples are typical of oceanic tholeiites, and there is no major variation between the different holes. Their most important feature lies in the ex- 
Table 3. Clinopyroxene analyses.

\begin{tabular}{|c|c|c|c|c|c|c|c|c|c|c|c|c|c|c|c|}
\hline \multirow{3}{*}{$\begin{array}{l}\text { Position } \\
\text { Analysis }\end{array}$} & \multicolumn{5}{|c|}{$\begin{array}{c}\text { Sample } \\
\text { 553A-46-2, } 99-103 \mathrm{~cm}\end{array}$} & \multicolumn{5}{|c|}{$\begin{array}{c}\text { Sample } \\
\text { 553A-59-4, 71-75 cm }\end{array}$} & \multicolumn{5}{|c|}{$\begin{array}{c}\text { Sample } \\
554 \mathrm{~A}-7-4,82-85 \mathrm{~cm}\end{array}$} \\
\hline & G & G & G & G & G & $\mathrm{C}$ & $\mathbf{R}$ & G & G & G & G & G & G & G & G \\
\hline & 8 & 9 & 10 & 11 & 12 & 13 & 14 & 15 & 16 & 17 & 18 & 19 & 20 & 21 & 22 \\
\hline \multicolumn{16}{|c|}{ Major element oxide (wt.\%) } \\
\hline $\mathrm{SiO}_{2}$ & 52.43 & 52.58 & 49.92 & 50.75 & 52.05 & 51.63 & 52.22 & 51.17 & 50.68 & 53.08 & 50.71 & 50.38 & 48.62 & 49.27 & 51.42 \\
\hline $\mathrm{TiO}_{2}$ & 0.35 & 0.34 & 0.62 & 0.63 & 0.36 & 0.51 & 0.36 & 0.44 & 0.69 & 0.22 & 0.45 & 0.75 & 0.96 & 1.04 & 0.44 \\
\hline $\mathrm{Al}_{2} \mathrm{O}_{3}$ & 1.05 & 1.05 & 1.25 & 1.54 & 1.83 & 3.06 & 2.24 & 0.98 & 1.72 & 1.91 & 0.92 & 1.09 & 0.92 & 1.21 & 1.71 \\
\hline $\mathrm{Cr}_{2} \mathrm{O}_{3}$ & 0.02 & 0.00 & 0.00 & 0.04 & 0.03 & 0.21 & 0.04 & 0.00 & 0.10 & 0.15 & 0.00 & 0.00 & 0.00 & 0.00 & 0.00 \\
\hline $\mathrm{FeO}^{*}$ & 20.14 & 21.04 & 21.14 & 17.08 & 10.03 & 9.01 & 11.27 & 23.86 & 17.86 & 7.41 & 27.03 & 26.35 & 26.26 & 23.52 & 12.22 \\
\hline $\mathrm{MnO}$ & 0.42 & 0.34 & 0.47 & 0.22 & 0.15 & 0.27 & 0.22 & 0.60 & 0.24 & 0.20 & 0.46 & 0.50 & 0.49 & 0.46 & 0.17 \\
\hline $\mathrm{MgO}$ & 20.25 & 19.12 & 13.97 & 13.41 & 17.04 & 17.07 & 17.25 & 18.31 & 14.59 & 17.89 & 14.27 & 11.27 & 9.31 & 8.33 & 15.31 \\
\hline $\mathrm{CaO}$ & 5.25 & 5.71 & 12.07 & 15.94 & 17.84 & 18.54 & 16.32 & 5.37 & 13.99 & 19.17 & 5.85 & 9.14 & 12.94 & 15.00 & 17.86 \\
\hline $\mathrm{Na}_{2} \mathrm{O}$ & 0.06 & 0.04 & 0.14 & 0.25 & 0.22 & 0.15 & 0.15 & 0.04 & 0.13 & 0.22 & 0.13 & 0.08 & 0.26 & 0.21 & 0.22 \\
\hline $\mathrm{K}_{2} \mathrm{O}$ & 0.00 & 0.00 & 0.00 & 0.00 & 0.00 & 0.02 & 0.01 & 0.00 & 0.03 & 0.00 & 0.00 & 0.00 & 0.00 & 0.00 & 0.00 \\
\hline Total & 99.97 & 100.22 & 99.58 & 99.86 & 99.55 & 100.47 & 100.08 & 100.77 & 100.03 & 100.25 & 99.82 & 99.56 & 99.76 & 99.04 & 99.35 \\
\hline $\mathrm{Ca}$ & 10.6 & 11.6 & 24.9 & 33.1 & 36.0 & 37.4 & 33.1 & 10.7 & 28.9 & 38.3 & 12.4 & 20.0 & 27.7 & 33.1 & 36.6 \\
\hline $\mathrm{Mg}$ & 56.9 & 54.3 & 40.2 & 38.8 & 47.9 & 47.8 & 48.7 & 51.0 & 41.9 & 49.8 & 42.1 & 34.2 & 27.7 & 25.6 & 43.6 \\
\hline $\mathrm{Fe}+\mathrm{Mn}$ & 32.5 & 34.1 & 34.9 & 28.1 & 16.1 & 14.6 & 18.2 & 38.3 & 29.2 & 11.9 & 45.5 & 45.8 & 44.6 & 41.3 & 19.8 \\
\hline
\end{tabular}

Note: Conventions as in Table 2.

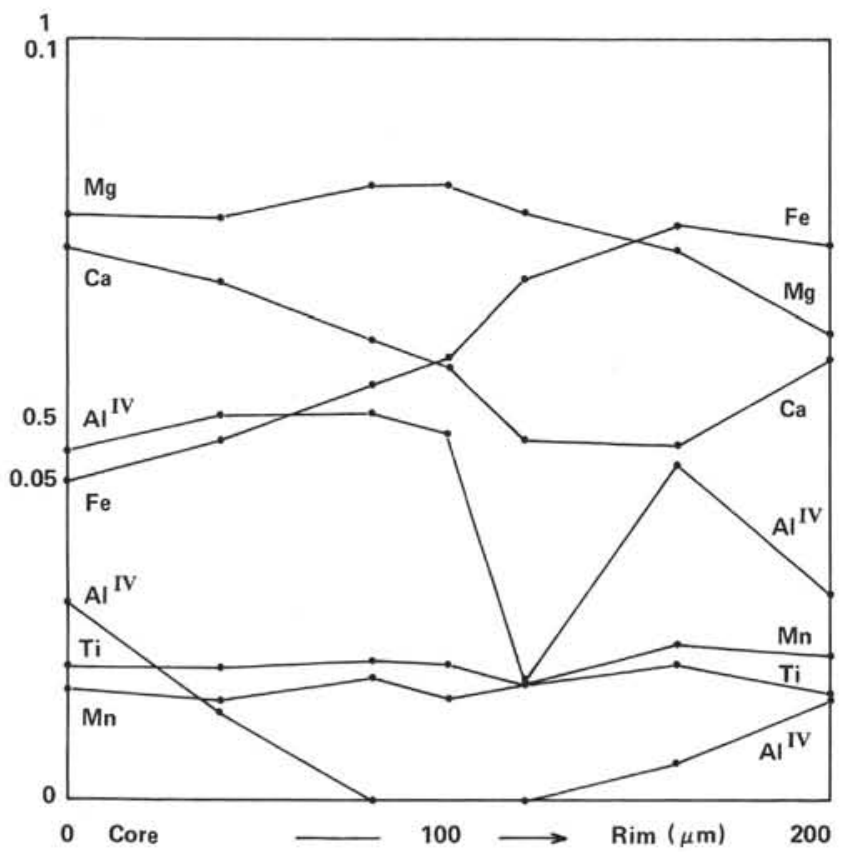

Figure 4. Core-to-rim crystallochemical variations in a clinopyroxene phenocryst from Sample 555-97-1, 34-38 cm (cations associated to six oxygens). (Heavy lines $=\mathrm{Ca}, \mathrm{Mg}, \mathrm{Fe}$ variations [scale $=0$ to 1 cation], normal lines $=$ other variations [scale $=0$ to 0.1 cation].)

treme depletion found for the most hygromagmaphile elements ( $\mathrm{Th}, \mathrm{Ta}, \mathrm{La}$, and $\mathrm{Nb}$ ), some concentrations of which are lower than the chondritic values. Such strongly depleted tholeiites have previously been found in basalts from the Costa Rica Rift, DSDP Legs 68-69 and 70 (Etoubleau et al., in press).

The concentrations of trace alkali elements in fresh Leg 81 samples (LOI $<1.5 \% ; \mathrm{K}_{2} \mathrm{O}<0.2 \%$ ) are typically very low ( $\mathrm{Rb}<2 \mathrm{ppm}) ; \mathrm{Cs}<0.1 \mathrm{ppm})$ and characteristic of oceanic tholeiites. They differ clearly from those of continental tholeiites (flood basalts) which are consistently enriched in $\mathrm{Rb}, \mathrm{Cs}$, and $\mathrm{Ba}$ with respect to ocean-floor basalts (Bertrand et al., 1982). The Leg 81 samples show trace alkali metal concentrations similar to those of oceanic tholeiites from the Celtic Sea passive margin, DSDP Leg 80 (Maury et al., in press), and also to the Preshal Mhor-type tholeiites from the British Tertiary Igneous Province (Thompson, 1982). In the altered samples from Leg 81, positive correlations are found between $\mathrm{Rb}, \mathrm{Cs}$, and the amounts of $\mathrm{K}_{2} \mathrm{O}$ and LOI (e.g., Sample 558-81-1, 110-115 cm; $\mathrm{Rb}=15.2 \mathrm{ppm}, \mathrm{K}_{2} \mathrm{O}=$ $2.23 \%$, LOI $=3.09 \%$ ). These correlations reflect the progressive alteration of basalt by seawater (Donnelly et al., 1979).

The high partition coefficient elements show important variations $(\mathrm{Cr}=380-55 \mathrm{ppm} ; \mathrm{Ni}=103-44 \mathrm{ppm})$ which are shown graphically in Figure 7 . None of the Leg 81 basalts can be considered a primary melt; their concentrations in $\mathrm{Cr}$ and $\mathrm{Ni}$ should be significantly higher $(\mathrm{Cr} \cong 600 \mathrm{ppm}, \mathrm{Ni} \cong 250 \mathrm{ppm})$ than those found; these concentrations are characteristic of derived liquids resulting from fractional crystallization. The good positive correlation between $\mathrm{Ni}$ and $\mathrm{Cr}$ shown in Figure 7, and the lack of correlation between them and the $\mathrm{K}_{2} \mathrm{O}$ or LOI values allow us to ascribe the $\mathrm{Cr}$ and $\mathrm{Ni}$ variations to the fractionation of $\mathrm{Cr}$ - and Ni-bearing minerals (chromiferous spinel and olivine), as previously shown for many ocean-floor basalt sequences (Bougault et al., 1979).

The most unusual geochemical feature of Hole 553A, $554 \mathrm{~A}$, and 555 basalts lies in their extreme depletion in the most hygromagmaphile elements $(\mathrm{Th}=0.013-$ $0.095 \mathrm{ppm} ; \mathrm{Ta}=0.025-0.100 \mathrm{ppm} ; \mathrm{La}=0.54-2.00$ $\mathrm{ppm} ; \mathrm{Nb}=0.3-2.9 \mathrm{ppm})$. Among 32 samples studied, 6 show Th concentrations lower than the chrondritic value $(0.028 \mathrm{ppm}$ following Bougault, 1980), and $5 \mathrm{Ta}$ concentrations are lower than $0.031 \mathrm{ppm}$ (chondritic concentration). The problems of accuracy for the measure- 
Table 3. (Continued).

\begin{tabular}{|c|c|c|c|c|c|c|c|c|c|c|c|c|c|c|}
\hline \multicolumn{5}{|c|}{$\begin{array}{c}\text { Sample } \\
55-90-3,54-57 \mathrm{~cm}\end{array}$} & \multicolumn{10}{|c|}{$\begin{array}{c}\text { Sample } \\
555-97-1,34-38 \mathrm{~cm} \\
\end{array}$} \\
\hline C & R & G & G & G & C & $\mathbf{R}$ & C & $\mathbf{R}$ & R & C & R & G & G & G \\
\hline 23 & 24 & 25 & 26 & 27 & 28 & 29 & 30 & 31 & 32 & 33 & 34 & 35 & 36 & 37 \\
\hline 50.25 & 48.58 & 52.94 & 51.03 & 49.05 & 52.38 & 50.87 & 51.45 & 51.23 & 51.09 & 51.23 & 50.18 & 52.02 & 51.48 & 51.55 \\
\hline 0.74 & 0.69 & 0.27 & 0.60 & 0.82 & 0.37 & 0.70 & 0.69 & 0.56 & 0.32 & 0.45 & 0.30 & 0.40 & 0.65 & 0.76 \\
\hline 1.75 & 1.00 & 1.84 & 2.17 & 0.96 & 2.01 & 1.79 & 2.00 & 1.48 & 0.55 & 0.79 & 0.45 & 2.87 & 1.61 & 1.15 \\
\hline 0.00 & 0.00 & 0.35 & 0.04 & 0.00 & 0.00 & 0.01 & 0.00 & 0.02 & 0.00 & 0.00 & 0.00 & 0.45 & 0.09 & 0.01 \\
\hline 18.15 & 28.72 & 7.14 & 13.14 & 28.97 & 8.05 & 14.00 & 11.34 & 13.36 & 27.79 & 25.95 & 32.89 & 5.60 & 13.48 & 18.39 \\
\hline 0.45 & 0.57 & 0.19 & 0.45 & 0.65 & 0.11 & 0.43 & 0.32 & 0.22 & 0.76 & 0.59 & 0.63 & 0.06 & 0.44 & 0.31 \\
\hline 14.27 & 6.56 & 17.20 & 14.39 & 8.61 & 15.77 & 13.50 & 14.68 & 14.31 & 14.53 & 14.98 & 10.23 & 16.46 & 13.48 & 11.12 \\
\hline 13.57 & 12.91 & 19.86 & 17.72 & 11.58 & 20.25 & 17.81 & 18.73 & 17.95 & 4.93 & 6.55 & 6.21 & 21.25 & 17.86 & 16.56 \\
\hline 0.22 & 0.19 & 0.25 & 0.26 & 0.11 & 0.18 & 0.20 & 0.28 & 0.23 & 0.05 & 0.05 & 0.05 & 0.21 & 0.23 & 0.17 \\
\hline 0.00 & 0.00 & 0.00 & 0.00 & 0.02 & 0.00 & 0.00 & 0.00 & 0.00 & 0.00 & 0.00 & 0.00 & 0.00 & 0.00 & 0.00 \\
\hline 99.40 & 99.22 & 100.04 & 99.80 & 100.77 & 99.12 & 99.31 & 99.49 & 99.36 & 100.02 & 100.59 & 100.94 & 99.32 & 99.32 & 100.02 \\
\hline 28.3 & 28.8 & 40.1 & 36.6 & 24.8 & 41.7 & 42.3 & 38.8 & 37.0 & 10.4 & 13.6 & 13.3 & 43.8 & 37.6 & 35.5 \\
\hline 41.4 & 20.3 & 48.3 & 41.4 & 25.7 & 45.2 & 48.7 & 42.3 & 41.1 & 42.6 & 43.3 & 30.5 & 47.1 & 39.5 & 33.2 \\
\hline 30.3 & 50.9 & 11.6 & 22.0 & 49.5 & 13.1 & 9.0 & 18.9 & 21.9 & 47.0 & 43.1 & 56.2 & 9.1 & 22.9 & 31.3 \\
\hline
\end{tabular}

Table 4. Selected analyses of groundmass Fe-Ti oxides.

\begin{tabular}{|c|c|c|c|c|c|c|c|c|c|c|c|c|c|}
\hline \multirow[b]{2}{*}{$\begin{array}{l}\text { Mineral } \\
\text { Analysis }\end{array}$} & \multicolumn{4}{|c|}{$\begin{array}{c}\text { Sample } \\
\text { 553A-46-2, 99-103 cm }\end{array}$} & \multicolumn{3}{|c|}{$\begin{array}{c}\text { Sample } \\
553 \mathrm{~A}-47-3,16-19 \mathrm{~cm} \\
\end{array}$} & \multicolumn{6}{|c|}{$\begin{array}{c}\text { Sample } \\
\text { 555-97-1, 34-38 cm }\end{array}$} \\
\hline & $\begin{array}{c}\text { MT } \\
38\end{array}$ & $\begin{array}{c}\text { MT } \\
39\end{array}$ & $\begin{array}{l}\text { IL } \\
40\end{array}$ & $\begin{array}{ll}\text { IL } \\
41\end{array}$ & $\begin{array}{c}\mathrm{MT} \\
42\end{array}$ & $\begin{array}{l}\text { IL } \\
43\end{array}$ & $\begin{array}{l}\text { IL } \\
44\end{array}$ & $\begin{array}{l}\text { MT } \\
45\end{array}$ & $\begin{array}{l}\mathrm{MT} \\
46\end{array}$ & $\begin{array}{c}\text { MT } \\
47\end{array}$ & $\begin{array}{c}\text { MT } \\
48\end{array}$ & $\begin{array}{l}\text { IL } \\
49\end{array}$ & $\begin{array}{l}\text { IL } \\
\text { S0 }\end{array}$ \\
\hline \multicolumn{14}{|c|}{ Major element oxide (wt.\%) } \\
\hline $\mathrm{SiO}_{2}$ & 0.18 & 0.08 & 0.06 & 0.04 & 0.12 & 0.15 & 0.10 & 0.11 & 0.14 & 0.13 & 0.09 & 0.00 & 0.09 \\
\hline $\mathrm{O}_{2}$ & 24.31 & 24.57 & 49.67 & 45.52 & 24.76 & 48.63 & 47.31 & 17.51 & 24.99 & 17.96 & 22.08 & 50.25 & 50.37 \\
\hline $\mathrm{Al}_{2} \mathrm{O}_{3}$ & 1.81 & 1.88 & 0.02 & 0.49 & 1.49 & 0.18 & 0.11 & 2.07 & 0.75 & 0.93 & 2.19 & 0.03 & 0.04 \\
\hline $\mathrm{Cr}_{2} \mathrm{O}_{3}$ & 0.00 & 0.09 & 0.00 & 0.05 & 0.03 & 0.15 & 0.00 & 0.10 & 0.00 & 0.03 & 0.00 & 0.00 & 0.00 \\
\hline $\mathrm{Fe}_{2} \mathrm{O}_{3} \mathrm{a}^{\mathrm{a}}$ & 18.13 & 17.67 & 6.39 & 13.88 & 18.02 & 5.80 & 8.12 & 32.91 & 19.18 & 33.25 & 23.07 & 3.10 & 4.47 \\
\hline $\mathrm{FeO}$ & 48.61 & 48.46 & 40.83 & 37.48 & 51.93 & 43.03 & 42.07 & 45.04 & 53.04 & 47.00 & 50.41 & 44.45 & 44.37 \\
\hline $\mathrm{MnO}$ & 3.07 & 3.06 & 0.35 & 0.38 & 1.25 & 0.44 & 0.40 & 0.29 & 0.36 & 0.39 & 0.38 & 0.38 & 0.43 \\
\hline $\mathrm{MgO}$ & 0.80 & 1.09 & 1.96 & 1.93 & 0.28 & 0.25 & 0.0 & 1.38 & 0.39 & 0.30 & 0.47 & 0.21 & 0.29 \\
\hline $\mathrm{CaO}$ & 0.12 & 0.09 & 0.06 & 0.08 & 0.16 & 0.13 & 0.24 & 0.09 & 0.04 & 0.00 & 0.02 & 0.08 & 0.05 \\
\hline $\mathrm{Na}_{2} \mathrm{O}$ & 0.00 & 0.04 & 0.00 & 0.03 & 0.01 & 0.00 & 0.00 & 0.03 & 0.00 & 0.00 & 0.00 & 0.00 & 0.00 \\
\hline $\mathrm{K}_{2} \mathrm{O}$ & 0.01 & 0.04 & 0.02 & 0.00 & 0.01 & 0.03 & 0.00 & 0.00 & 0.00 & 0.00 & 0.00 & 0.00 & 0.00 \\
\hline Total & 97.04 & 97.07 & 99.36 & 99.88 & 98.06 & 98.79 & 98.43 & 99.53 & 98.89 & 99.99 & 98.71 & 98.50 & 100.11 \\
\hline Usp or $\mathrm{He}^{\mathrm{b}}$ & 72.8 & 73.5 & 6.0 & 13.2 & 73.3 & 5.6 & 7.3 & 51.5 & 72.3 & 51.9 & 65.7 & 3.0 & 4.3 \\
\hline
\end{tabular}

Note: $\mathrm{MT}=$ titanomagnetites, $\mathrm{IL}=$ hemoilmenites.

$\mathrm{a} \mathrm{Fe}_{2} \mathrm{O}_{3}$ estimated by $\mathrm{R}_{3} \mathrm{O}_{4}$ (MT) or $\mathrm{R}_{2} \mathrm{O}_{3}$ (IL) stoichiometry.
b Ulvöspinel (Usp) and hematite (He) molar percentages calculated following Carmichael's (1967) method.

ment of such low concentrations have been discussed extensively by Etoubleau et al. (in press), for samples from the Costa Rica Rift showing the same characteristics. Leg 81 drillings have thus made available the second DSDP occurrence of such strongly LREE-depleted basalts. Of course the extended Coryell-Masuda diagrams (Bougault, 1980) shown in Figures 8 and 9 show typically "depleted" patterns characteristic of deep oceanic tholeiites, even for samples showing no extreme depletion in the most hygromagmaphile elements (e.g., Samples 552-22-1, 20-24 cm, and 555-69-4, 88-92 cm). The $\mathrm{Y} / \mathrm{Tb}$ and $\mathrm{Zr} / \mathrm{Hf}$ ratios of Leg 81 basalts are close to the chondritic values of 50 and 40 , respectively. But the values of ratios of concentrations of the most hygromagmaphile elements ( $\mathrm{Th}, \mathrm{Nb}, \mathrm{Ta}$, and $\mathrm{La}$ ) are almost impossible to determine (at least sample by sample) because of the extremely low abundances of these elements, as already mentioned; the lack of precision at these levels of concentration would induce values of ratios that could be erroneous. As an example, the precision of $\mathrm{Nb}$ determination was discussed by Etoubleau et al. (in press); it is a function of both the reproducibility of measurements (counting statistics) and of a constant error that results from instrumental settings. The approximate value of each contribution is $1 \mathrm{ppm}$ for $\mathrm{Nb}$. The second term can be improved and was reduced to a fraction of $1 \mathrm{ppm}$ for on board measurements during Leg 82 as a result of very careful instrument adjustments. Nevertheless, in the case of Leg 81 results, even if the second term can be reduced, the range of variation of the $\mathrm{Nb}$ concentration is within $2 \mathrm{ppm}$.

Such a range of variation combined with a precision of $\pm 1 \mathrm{ppm}$ corresponding only to counting statistics makes it impossible to find any correlation with another element.

We will consider the most important result to be represented by the extremely low abundances of these elements (Th, Ta, Nb, and La). Nevertheless, despite the aforementioned limitations for considering ratios of these elements, one can observe a good correlation between $\mathrm{La}$ and $\mathrm{Ta}$ in Figure 10.

Usually, the $\mathrm{La} / \mathrm{Ta}$ ratio is 9 ( 1 when normalized to chondrite) for mid-ocean ridge basalts (MORBs) that present flat to enriched Coryell-Masuda patterns and 


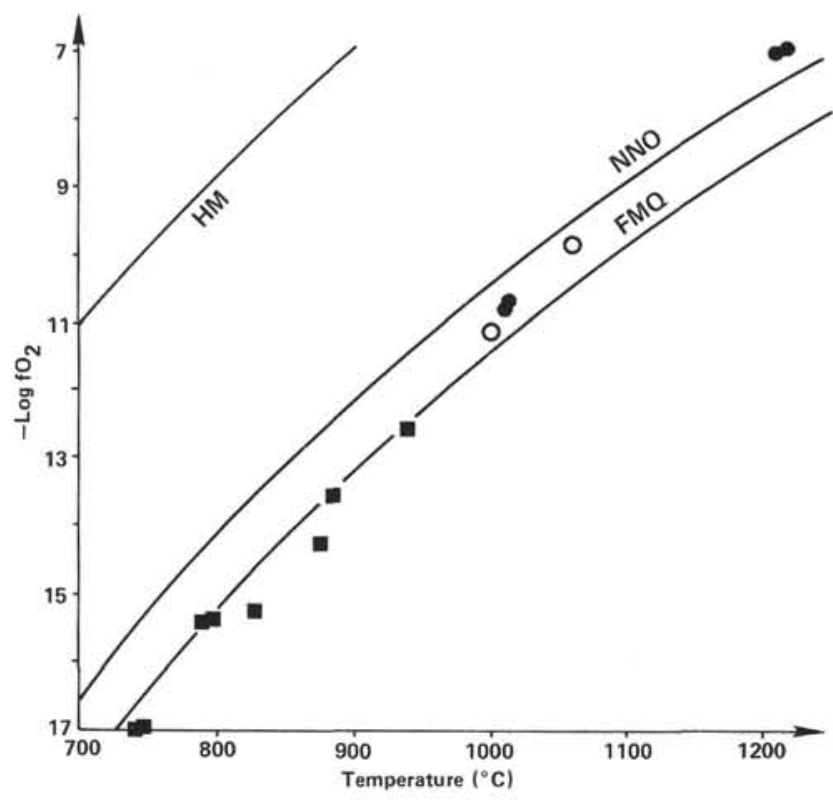

Figure 5. $\mathrm{T} / \mathrm{Log} \mathrm{fO}_{2}$ data for coexisting $\mathrm{Fe}-\mathrm{Ti}$ oxides. (Filled circles $=$ Sample 553A-46-2, 99-103 cm, open circles = Sample 553A-47-3, $16-19 \mathrm{~cm}$, filled squares $=$ Sample $555-97-1,34-38$.

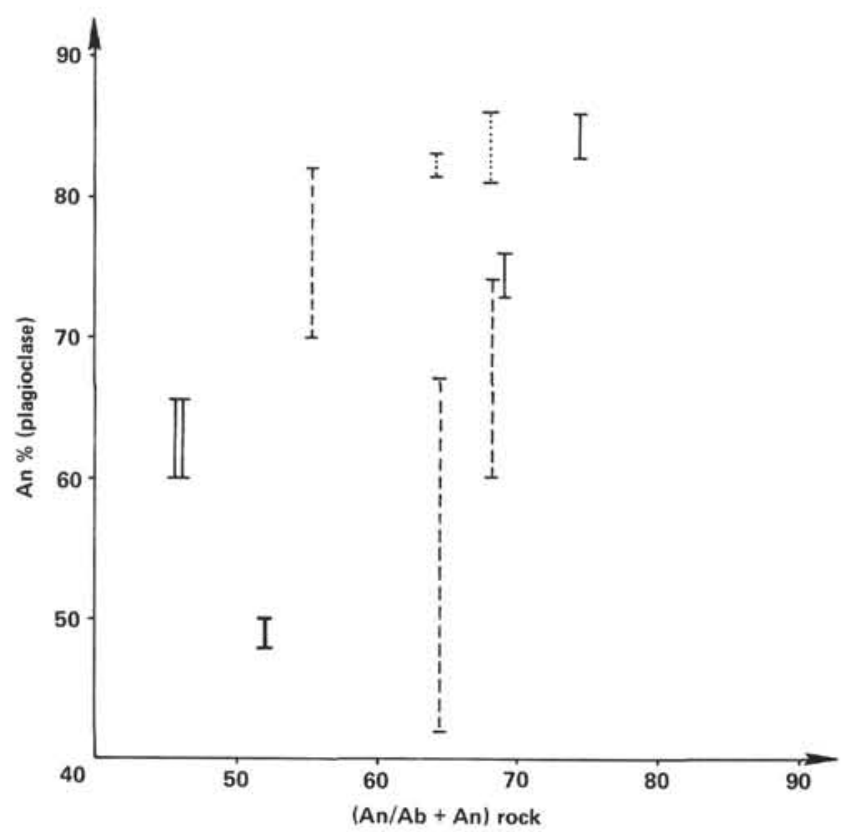

Figure 6. Correlation between modal and normative plagioclase compositions. The compositions of modal plagioclases are those of phenocrysts (their extreme rims, the compositions of which are similar to those of groundmass plagioclases, have not been considered). (Double line $=$ Hole 552 plagioclases, single line $=$ Hole $553 \mathrm{~A}$ plagioclases, dotted line $=$ Hole $554 \mathrm{~A}$ plagioclases, dashed line $=$ Hole 555 plagioclases.)

the $\mathrm{La}$ /Ta ratio is 19 ( $\cong 2$ for normalized ratio) in the case of typically depleted MORBs; some intermediate values have been found (Bougault et al., 1979; Bougault, 1980). In the case of Leg 81 samples, Figure 10 clearly shows a $\mathrm{La} / \mathrm{Ta}$ ratio close to 19 even if somewhat higher. As already mentioned, we will not discuss the exact val-
Table 5. Feldspar analyses.

\begin{tabular}{|c|c|c|c|c|c|c|c|c|c|c|}
\hline \multirow[b]{2}{*}{$\begin{array}{l}\text { Position } \\
\text { Analysis }\end{array}$} & \multicolumn{10}{|c|}{$\begin{array}{c}\text { Sample } \\
555-90-3,54-57 \mathrm{~cm}\end{array}$} \\
\hline & $\begin{array}{l}C \\
51\end{array}$ & 52 & 53 & 54 & 55 & $\begin{array}{l}R \\
56\end{array}$ & $\begin{array}{l}\text { G } \\
57\end{array}$ & $\begin{array}{l}\mathrm{G} \\
58\end{array}$ & $\begin{array}{l}\mathrm{G} \\
59\end{array}$ & $\begin{array}{l}G \\
60\end{array}$ \\
\hline \multicolumn{11}{|c|}{ Major element oxide (wt.\%) } \\
\hline $\begin{array}{l}\mathrm{SiO}_{2} \\
\mathrm{Al}_{2} \mathrm{O}_{3} \\
\mathrm{Fe}_{2} \mathrm{O}_{3} \mathrm{a} \\
\mathrm{MgO} \\
\mathrm{CaO} \\
\mathrm{Na}_{2} \mathrm{O} \\
\mathrm{K}_{2} \mathrm{O}\end{array}$ & $\begin{array}{r}50.95 \\
30.90 \\
0.78 \\
0.12 \\
13.94 \\
3.72 \\
0.06\end{array}$ & $\begin{array}{r}54.58 \\
28.39 \\
0.77 \\
0.10 \\
11.41 \\
5.03 \\
0.06\end{array}$ & $\begin{array}{r}54.73 \\
28.10 \\
0.88 \\
0.11 \\
10.92 \\
5.29 \\
0.02\end{array}$ & $\begin{array}{r}56.03 \\
27.26 \\
0.97 \\
0.05 \\
9.86 \\
5.67 \\
0.01\end{array}$ & $\begin{array}{r}58.41 \\
26.10 \\
0.76 \\
0.07 \\
8.72 \\
6.43 \\
0.07\end{array}$ & $\begin{array}{r}59.72 \\
25.49 \\
0.82 \\
0.03 \\
7.21 \\
7.26 \\
0.09\end{array}$ & $\begin{array}{r}51.17 \\
30.12 \\
1.38 \\
0.10 \\
13.31 \\
3.88 \\
0.03\end{array}$ & $\begin{array}{r}54.36 \\
28.10 \\
1.10 \\
0.06 \\
11.03 \\
5.06 \\
0.02\end{array}$ & $\begin{array}{r}56.11 \\
27.09 \\
1.17 \\
0.18 \\
9.69 \\
5.58 \\
0.09\end{array}$ & $\begin{array}{r}65.92 \\
20.50 \\
0.55 \\
0.00 \\
1.55 \\
9.43 \\
1.97\end{array}$ \\
\hline Total & 100.47 & 100.34 & 100.05 & 99.85 & 100.56 & 100.62 & 99.99 & 99.73 & 99.91 & 99.92 \\
\hline $\begin{array}{l}\mathrm{Na} \\
\mathrm{K} \\
\mathrm{Ca}\end{array}$ & $\begin{array}{r}32.5 \\
0.3 \\
67.2\end{array}$ & $\begin{array}{r}44.2 \\
0.3 \\
55.6\end{array}$ & $\begin{array}{r}46.7 \\
0.1 \\
53.2\end{array}$ & $\begin{array}{r}51.0 \\
0.0 \\
49.0\end{array}$ & $\begin{array}{r}56.9 \\
0.4 \\
42.7\end{array}$ & $\begin{array}{r}64.2 \\
0.5 \\
35.3\end{array}$ & $\begin{array}{r}34.5 \\
0.2 \\
65.3\end{array}$ & $\begin{array}{r}45.3 \\
0.1 \\
54.6\end{array}$ & $\begin{array}{r}50.7 \\
0.6 \\
48.7\end{array}$ & $\begin{array}{r}81.4 \\
11.2 \\
7.4\end{array}$ \\
\hline
\end{tabular}

ue of this ratio but its value is much closer to 19 than 9 . As a consequence, and as far as hygromagmaphile elements are concerned, the basalts recovered during Leg 81 are similar in all ways to typical depleted MORBs.

This $\mathrm{Ta}$ (and $\mathrm{Nb}$ ) behavior is known as $\mathrm{Ta}, \mathrm{Nb}$ anomaly (Bougault, 1980). In basalts from mid-oceanic ridges (North Atlantic, Leg 49, Wood et al., 1979; PacificCosta Rica Rift, Leg 69, Etoubleau et al., in press), the $\mathrm{Th} / \mathrm{Ta}$ ratio is close to 1 while in subduction zones this ratio is very variable and higher than 10 (Joron and Treuil, 1977; Joron et al., 1978; Briqueu et al., 1983). In basalts from Hole 555 , the Th/Ta ratio is close to 2-3 and significantly different from the values found in the deep-oceanic tholeiites and the other holes from Leg 81 (Fig. 11). Such a ratio has been reported (Kharbouch, 1982; Beziat, 1983) in basalts from the continental margin and seems characteristic of this area. Further results will be necessary to corroborate this relationship.

It is thus important to note that typical depleted MORBs not only are present on "normal" zero-age ridge segments in a context of "steady state" spreading but also are found in very early stages of the opening of an ocean. This observation implies that both magmatic processes and mantle source material are not necessarily different in the early stages of opening of an ocean than they are today on the mid-Atlantic Ridge or on the East Pacific Rise.

\section{DISCUSSION}

\section{Magmatic Affinities of Leg-81 Basalts}

The geochemical and mineralogical data discussed here show clearly that, whatever their structural position with respect to the Rockall microcontinent, the Paleocene to early Eocene Leg 81 basalts are strongly LREEdepleted oceanic tholeiites. Their extreme depletion in the most hygromagmaphile trace elements $(\mathrm{Th}, \mathrm{Ta}, \mathrm{La}$, and $\mathrm{Nb}$ ) compared to the data of the extensively studied North Atlantic Ridge basalts supports the notion of important mantle heterogeneities beneath the North Atlantic. Previous data (Maury et al., in press) have shown that basalts drilled during DSDP Leg 80 (Hole 551) over the continental basement of Goban Spur (Celtic Sea passive margin, NE Atlantic) are also LREE-depleted 
Table 6. Trace-element data (ppm).

\begin{tabular}{|c|c|c|c|c|c|c|c|c|c|c|c|c|c|c|c|c|c|c|}
\hline \multicolumn{19}{|c|}{ Sample (interval in cm) } \\
\hline & $\begin{array}{l}552-22-1, \\
20-24\end{array}$ & $\begin{array}{c}553 \mathrm{~A}-40-1, \\
82-85\end{array}$ & $\underset{37-43}{553 \mathrm{~A}-43-2}$ & $\begin{array}{c}553 \mathrm{~A}-44-2 \\
51-55\end{array}$ & $\begin{array}{c}553 \mathrm{~A}-46-2 \\
99-103\end{array}$ & $\begin{array}{c}553 \mathrm{~A}-46-3 \\
141-145\end{array}$ & $\begin{array}{c}553 \mathrm{~A}-47-3 \\
16-19\end{array}$ & $\begin{array}{c}553 \mathrm{~A}-48-4 \\
68-71\end{array}$ & $\begin{array}{c}553 \mathrm{~A}-49-3 \\
81-84\end{array}$ & $\begin{array}{c}553 \mathrm{~A}-50-2 \\
89-93\end{array}$ & $\begin{array}{c}553 \mathrm{~A}-51-2 \\
99-102\end{array}$ & $\begin{array}{c}553 \mathrm{~A}-52-2 \\
47-50\end{array}$ & $\begin{array}{c}553 \mathrm{~A}-54-4 \\
51-54\end{array}$ & $\begin{array}{c}553 \mathrm{~A}-55-5 \\
14-17\end{array}$ & $\begin{array}{c}553 \mathrm{~A}-58-2 \\
78-81\end{array}$ & $\begin{array}{c}553 \mathrm{~A}-59-4 \\
71-75\end{array}$ & $\begin{array}{c}554 \mathrm{~A}-7-2, \\
66-69\end{array}$ & $\begin{array}{c}554 \mathrm{~A}-7-4 \\
82-85\end{array}$ \\
\hline \multicolumn{19}{|c|}{ Major element oxide (wt. \%) } \\
\hline $\mathrm{SiO}_{2}$ & 47.33 & 53.22 & 50.68 & 51.26 & 49.64 & 49.17 & 48.95 & 49.44 & 49.25 & 48.71 & 49.42 & 48.88 & 48.78 & 49.10 & 48.70 & 49.11 & 49.68 & 50.20 \\
\hline $\mathrm{TiO}_{2}^{2}$ & 3.63 & 1.40 & 1.57 & 1.47 & 1.16 & 1.15 & 1.50 & 1.42 & 1.42 & 0.98 & 1.05 & 1.08 & 1.52 & 1.01 & 1.00 & 0.97 & 1.04 & 1.06 \\
\hline $\mathrm{Al}_{2} \mathrm{O}_{3}$ & 11.73 & 13.83 & 13.74 & 13.62 & 13.55 & 13.46 & 13.17 & 13.43 & 13.37 & 13.70 & 14.15 & 14.25 & 14.88 & 12.95 & 15.29 & 14.26 & 13.51 & 13.67 \\
\hline $\mathrm{Fe}_{2} \mathrm{O}_{3} \cdot \mathrm{at}$ & 18.50 & 13.86 & 15.49 & 14.98 & 14.34 & 14.39 & 15.79 & 15.30 & 15.61 & 12.72 & 13.22 & 12.55 & 14.08 & 14.57 & 10.94 & 12.67 & 14.71 & 13.48 \\
\hline $\mathrm{MnO}$ & 0.12 & 0.22 & 0.17 & 0.24 & 0.28 & 0.26 & 0.23 & 0.31 & 0.23 & 0.26 & 0.28 & 0.18 & 0.29 & 0.26 & 0.23 & 0.28 & 0.21 & 0.21 \\
\hline $\mathrm{MgO}$ & 9.00 & 5.51 & 5.95 & 6.21 & 7.69 & 7.82 & 7.36 & 7.28 & 7.20 & 8.41 & 7.70 & 7.55 & 7.01 & 8.75 & 8.51 & 8.26 & 6.76 & 7.00 \\
\hline $\mathrm{CaO}$ & 4.14 & 8.80 & 8.67 & 9.90 & 11.52 & 10.63 & 10.35 & 10.95 & 11.16 & 11.63 & 11.75 & 11.79 & 18.93 & 10.28 & 11.70 & 12.07 & 11.67 & 11.95 \\
\hline $\mathrm{Na}_{2} \mathrm{O}$ & 2.53 & 2.72 & 2.22 & 2.18 & 1.63 & 1.62 & 1.53 & 1.78 & 1.49 & 1.28 & 1.53 & 1.60 & 1.78 & 1.62 & 1.90 & 1.31 & 1.52 & 1.87 \\
\hline $\mathrm{K}_{2} \mathrm{O}$ & 0.15 & 0.09 & 0.11 & 0.04 & 0.02 & 0.01 & 0.03 & 0.01 & 0.02 & 0.01 & 0.01 & 0.02 & 0.02 & 0.00 & 0.01 & 0.01 & 0.32 & 0.16 \\
\hline $\begin{array}{l}\mathrm{P}_{2}^{2} \mathrm{O}_{5} \\
\mathrm{LOI}\end{array}$ & 0.30 & 0.17 & 0.14 & 0.16 & 0.11 & 0.16 & 0.15 & 0.14 & 0.10 & 0.13 & 0.14 & 0.14 & 0.14 & 0.13 & 0.12 & 0.11 & 0.11 & 0.09 \\
\hline $1050^{\circ}$ & 2.16 & 0.44 & 0.75 & 0.43 & 0.00 & 0.07 & 0.81 & 0.26 & 0.07 & 1.16 & 0.51 & 0.86 & 1.57 & 1.10 & 1.31 & 0.55 & 0.07 & 0.13 \\
\hline Total & 99.59 & 100.26 & 99.49 & 100.49 & 99.96 & 99.69 & 99.88 & 100.33 & 99.96 & 98.96 & 99.75 & 98.90 & 99.00 & 99.77 & 99.71 & 99.60 & 99.60 & 99.56 \\
\hline Q & 2.48 & 7.07 & 5.66 & 5.12 & 2.35 & 1.74 & 3.63 & 2.39 & 3.36 & 2.78 & 2.66 & 2.39 & 4.35 & 1.83 & & 2.39 & 2.99 & 2.26 \\
\hline or & 0.92 & 0.54 & 0.67 & 0.24 & 0.12 & 0.06 & 0.18 & 0.06 & 0.12 & 0.06 & 0.06 & 0.12 & 0.12 & & 0.06 & 0.06 & 1.92 & 0.96 \\
\hline ab & 22.31 & 23.31 & 19.27 & 18.66 & 13.96 & 13.91 & 13.24 & 15.24 & 12.79 & 11.19 & 13.18 & 13.95 & 15.64 & 14.06 & 16.48 & 11.31 & 13.08 & 16.05 \\
\hline an & 19.57 & 25.60 & 27.91 & 27.59 & 29.97 & 29.88 & 29.65 & 28.98 & 30.17 & 32.66 & 32.31 & 32.62 & 33.82 & 28.80 & 34.02 & 33.68 & 26.60 & 28.85 \\
\hline Co & 0.55 & & & & & & & & & & & & & & & & & \\
\hline $\begin{array}{l}\text { wo } \\
\text { di en }\end{array}$ & & $\begin{array}{l}7.36 \\
3.38\end{array}$ & $\begin{array}{l}.42 \\
2.92\end{array}$ & $\begin{array}{l}8.83 \\
4.13\end{array}$ & $\begin{array}{r}11.37 \\
5.87\end{array}$ & $\begin{array}{r}1.58 \\
6.01\end{array}$ & $\begin{array}{l}9.17 \\
4.52\end{array}$ & $\begin{array}{r}10.51 \\
5.19\end{array}$ & $\begin{array}{r}10.60 \\
5.19\end{array}$ & $\begin{array}{r}10.92 \\
6.09\end{array}$ & $\begin{array}{r}10.95 \\
5.83\end{array}$ & $\begin{array}{r}11.20 \\
6.08\end{array}$ & $\begin{array}{l}4.73 \\
2.41\end{array}$ & $\begin{array}{l}9.49 \\
5.09\end{array}$ & $\begin{array}{r}10.35 \\
6.13\end{array}$ & $\begin{array}{r}11.17 \\
6.19\end{array}$ & $\begin{array}{r}11.95 \\
5.76\end{array}$ & $\begin{array}{r}12.84 \\
6.55\end{array}$ \\
\hline 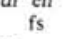 & & $\begin{array}{l}3.38 \\
3.91\end{array}$ & 3.46 & $\begin{array}{l}4.13 \\
4.60\end{array}$ & 5.20 & $\begin{array}{l}0.01 \\
5.25\end{array}$ & $\begin{array}{l}4.32 \\
4.48\end{array}$ & 5.11 & 5.23 & $\begin{array}{l}0.07 \\
4.41\end{array}$ & $\begin{array}{l}3.83 \\
4.78\end{array}$ & $\begin{array}{l}0.08 \\
4.73\end{array}$ & 2.21 & $\begin{array}{l}3.09 \\
4.09\end{array}$ & $\begin{array}{l}0.13 \\
3.70\end{array}$ & $\begin{array}{l}0.19 \\
4.56\end{array}$ & $\begin{array}{l}.7 .60 \\
6.00\end{array}$ & $\begin{array}{l}0.35 \\
5.98\end{array}$ \\
\hline en & 23.36 & 10.52 & 12.29 & 11.51 & 13.52 & 13.76 & 14.23 & 13.15 & 13.00 & 15.55 & 13.70 & 13.30 & 15.72 & 17.26 & 14.61 & 14.80 & 11.36 & 11.13 \\
\hline Fs & 18.69 & 12.15 & 14.56 & 12.81 & 11.98 & 12.02 & 14.11 & 12.94 & 13.11 & 11.26 & 11.23 & 10.35 & 14.47 & 13.84 & 8.82 & 10.90 & 11.82 & 10.16 \\
\hline $\begin{array}{l}\mathrm{Fo} \\
\mathrm{Fa}\end{array}$ & & & & & & & & & & & & & & & $\begin{array}{l}0.69 \\
0.46\end{array}$ & & & \\
\hline $\mathrm{Fa}$ & & & & & & & & & & 286 & & & & & 0.46 & & & \\
\hline $\mathrm{mt}$ & $\begin{array}{l}4.19 \\
7.19\end{array}$ & 3.05 & 3.46 & $\begin{array}{l}3.30 \\
283\end{array}$ & $\begin{array}{l}3.16 \\
2.23\end{array}$ & 3.18 & & $\begin{array}{l}3.37 \\
2.73\end{array}$ & $\begin{array}{l}3.45 \\
2.74\end{array}$ & $\begin{array}{l}2.86 \\
1.92\end{array}$ & $\begin{array}{r}2.93 \\
2.03\end{array}$ & 2.81 & 3.18 & 3.25 & 2.44 & 2.81 & 3.25 & $\begin{array}{l}2.97 \\
2.04\end{array}$ \\
\hline il & 7.19 & 2.6 & 3.06 & 2.8 & $\begin{array}{r}2.23 \\
0.26\end{array}$ & $\begin{array}{l}2.22 \\
0.39\end{array}$ & $\begin{array}{l}2.91 \\
0.36\end{array}$ & $\begin{array}{r}2.73 \\
0.34\end{array}$ & $\begin{array}{l}2.74 \\
0.24\end{array}$ & $\begin{array}{l}1.92 \\
0.32\end{array}$ & $\begin{array}{r}2.03 \\
0.34\end{array}$ & 2.1 & 3. & 1.9 & 1.9 & 1.88 & 2.01 & 2.04 \\
\hline $\mathrm{ap}$ & 0.74 & $\begin{array}{r}0.41 \\
26.22\end{array}$ & 0.34 & $\begin{array}{r}0.38 \\
28.03\end{array}$ & $\begin{array}{r}0.26 \\
34.14\end{array}$ & $\begin{array}{r}0.39 \\
3451\end{array}$ & $\begin{array}{r}0.36 \\
33.51\end{array}$ & $\begin{array}{r}0.34 \\
331.45\end{array}$ & $\begin{array}{r}0.24 \\
31.32\end{array}$ & $\begin{array}{r}0.32 \\
39.28\end{array}$ & $\begin{array}{r}0.34 \\
35.95\end{array}$ & $\begin{array}{r}0.34 \\
3657\end{array}$ & 0.34 & 0.32 & 0.29 & 0.27 & 0.27 & $\begin{array}{r}0.22 \\
32.75\end{array}$ \\
\hline $\begin{array}{l}\mathrm{Sl} \\
\mathrm{Dl}^{\mathrm{c}}\end{array}$ & $\begin{array}{l}31.63 \\
25.71\end{array}$ & $\begin{array}{l}26.22 \\
30.92\end{array}$ & $\begin{array}{l}26.57 \\
25.59\end{array}$ & $\begin{array}{l}28.03 \\
24.02\end{array}$ & $\begin{array}{l}34.14 \\
16.43\end{array}$ & $\begin{array}{l}34.31 \\
15.71\end{array}$ & $\begin{array}{l}31.51 \\
17.05\end{array}$ & $\begin{array}{l}31.43 \\
17.69\end{array}$ & $\begin{array}{l}11.32 \\
16.27\end{array}$ & $\begin{array}{l}19.28 \\
14.02\end{array}$ & $\begin{array}{l}35.95 \\
15.90\end{array}$ & $\begin{array}{l}36.57 \\
11646\end{array}$ & $\begin{array}{r}32.20 \\
201\end{array}$ & $\begin{array}{l}36.85 \\
15.85\end{array}$ & $\begin{array}{l}41.52 \\
1655\end{array}$ & $\begin{array}{l}38.85 \\
1.37\end{array}$ & $\begin{array}{l}30.66 \\
177.96\end{array}$ & $\begin{array}{l}32.75 \\
19.26\end{array}$ \\
\hline
\end{tabular}

a $\mathrm{Fe}_{2} \mathrm{O}_{3}{ }^{*}$ represents total iron as $\mathrm{Fe}_{2} \mathrm{O}_{3}$. The $\mathrm{CIPW}$ norms are calculated with $85 \%$ of total iron as $\mathrm{FeO}$ and $15 \%$ as $\mathrm{Fe}_{2} \mathrm{O}_{3}$. c Differentiation index. 
Table 7. Trace element data (ppm) for international rock standards used for instrumental neutron-activation analysis.

\begin{tabular}{lccc}
\hline Element & $\begin{array}{c}\text { Reference } \\
\text { concentrations } \\
\text { in GS-N }\end{array}$ & BE-N & $\begin{array}{c}\text { Concentrations obtained } \\
\text { in BCR-I using GS-N } \\
\text { reference concentrations }\end{array}$ \\
\hline $\mathrm{Th}$ & 40.8 & 10.1 & 5.96 \\
$\mathrm{Hf}$ & 6.5 & 5.6 & 5.0 \\
$\mathrm{Ba}$ & 1380 & 966 & 662 \\
$\mathrm{Ta}$ & 2.8 & 6.60 & 0.91 \\
$\mathrm{Co}$ & 65 & 61.4 & 37.7 \\
$\mathrm{~Tb}$ & 0.54 & 1.09 & 0.95 \\
$\mathrm{Sc}$ & 7.3 & 24.8 & 33.0 \\
$\mathrm{Rb}$ & 180 & 44.4 & 46.6 \\
$\mathrm{Zr}$ & 250 & 285 & 190 \\
$\mathrm{Cs}$ & 5.43 & 0.69 & 0.91 \\
$\mathrm{U}$ & 7.74 & 2.42 & 1.65 \\
$\mathrm{La}$ & 70 & 80 & 24.7 \\
$\mathrm{Eu}$ & 1.60 & 3.70 & 1.97 \\
$\mathrm{Ni}$ & 34 & 278 & 9.4 \\
$\mathrm{Ce}$ & 130 & 148 & 51.5 \\
\hline
\end{tabular}

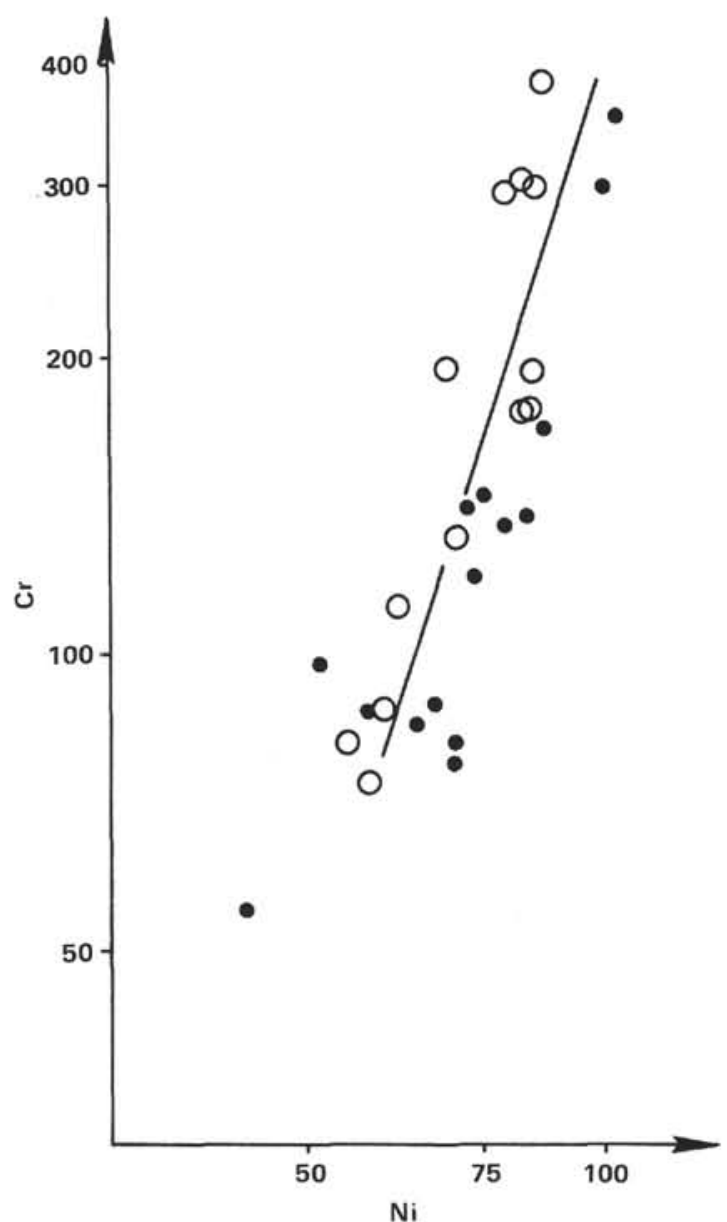

Figure 7. $\mathrm{Cr}-\mathrm{Ni}$ correlation for basalts from Hole 553A (filled circles) and Hole 555 (open circles).

oceanic tholeiites. The chemistry of these two basaltic sequences overlying the continental basements of North Atlantic margins is clearly different from that of the LREE-enriched and comparatively $\mathrm{Rb}-, \mathrm{Cs}-$, and $\mathrm{Ba}-$ rich basalts of continental tholeiitic (flood basalts) par-

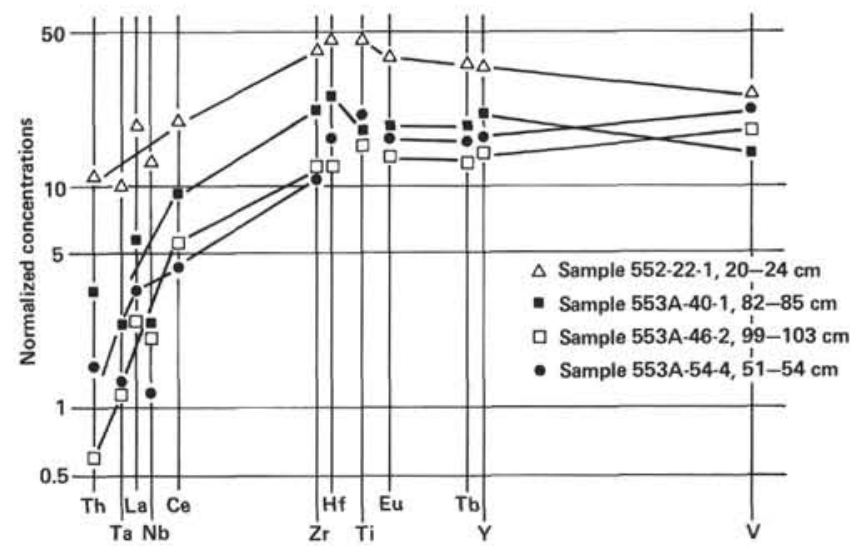

Figure 8. Extended Coryell-Masuda plots for selected samples from Holes 552 and 553A.

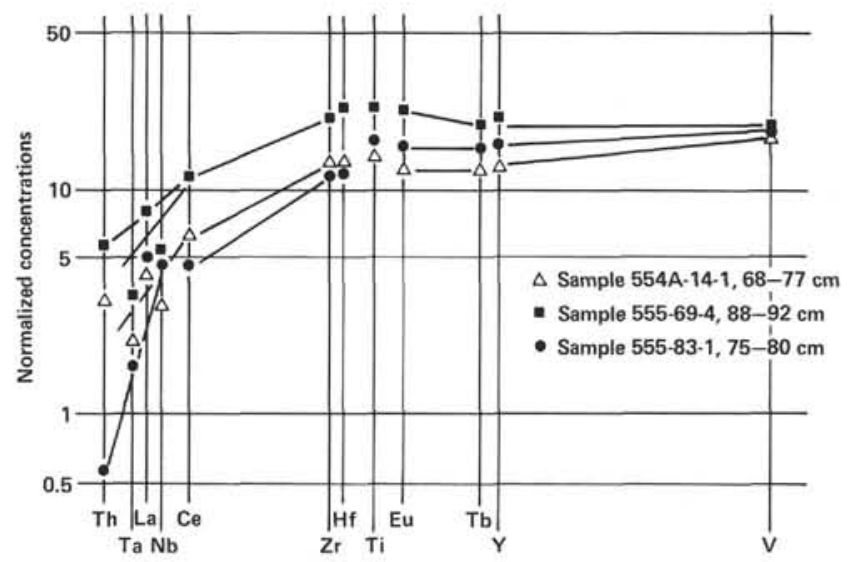

Figure 9. Extended Coryell-Masuda plots for selected samples from Holes 554A and 555.

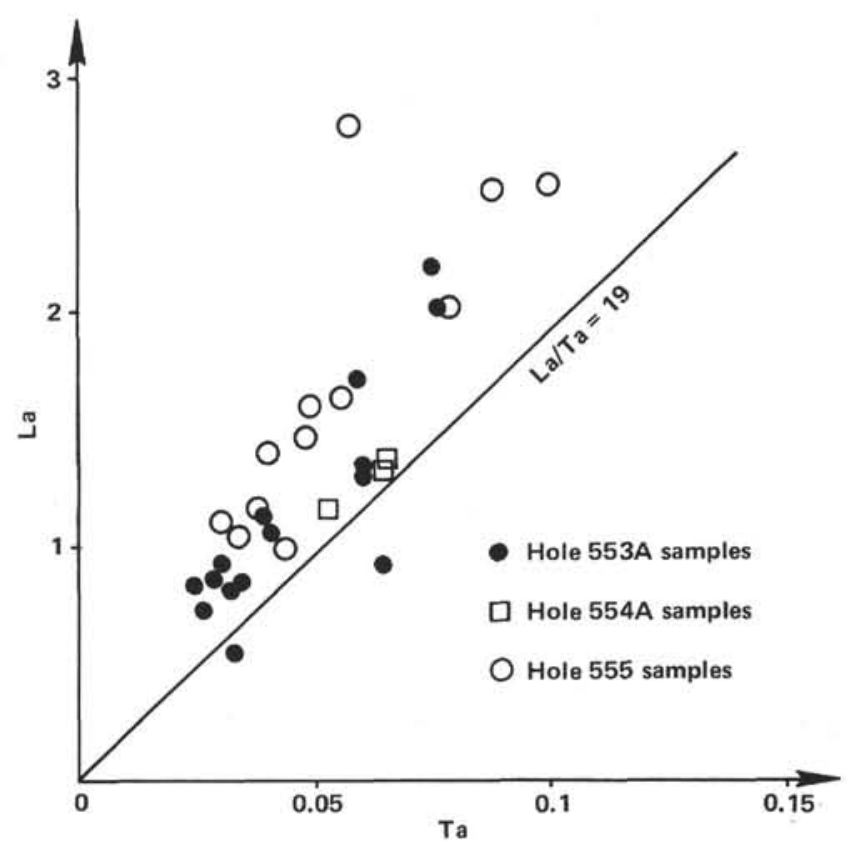

Figure 10. La/Ta plot. 


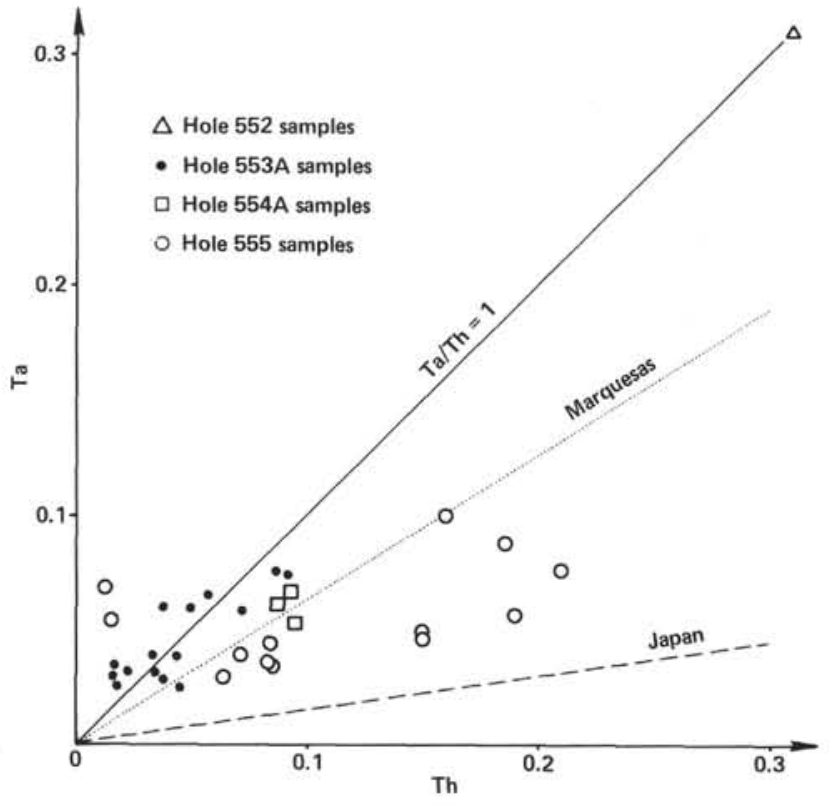

Figure 11. $\mathrm{Ta} / \mathrm{Th}$ plot.

entage which occur as numerous sills, dikes, and lava flows on the European, African, and American margins of the North Atlantic (Bertrand et al., 1982; Weigand and Ragland, 1970; Ragland et al., 1971; Philpotts and Schnetzler, 1968). These continental tholeiites, of Triassic to Liassic age, are older than the Upper Cretaceous Leg 80 basalts and than the Rockall Plateau basaltic sequences: it may thus be inferred that mechanisms of basaltic magma generation associated with oceanization may have changed during the complex history of the opening of the North Atlantic, and that LREE-depleted oceanic basalts may, in the latest stages, have been directly emplaced on a continental basement without previous production of LREE-enriched flood basalts.

\section{Comparison with Other Thulean Basalts}

Basaltic sequences of Paleocene to Eocene age outcrop in the Faeroe Islands (Noe-Nygaard and Rasmussen, 1968), in East Greenland (Beckinsale et al., 1970), and in the British Tertiary Province including Antrim Plateau basalts, Northern Ireland, and the extensively studied Hebridean Province of western Scotland (Brown, 1982; see Fig. 1). As a whole the geochemistry of Leg 81 basalts contrasts with that of most of these basaltic sequences, in which LREE-enriched alkalic or transitional magmas do predominate (Schilling and Noe-Nygaard, 1974; Thompson, 1982). However some similarities do appear, and further detailed comparisons are needed to place Leg 81 basalts in the magmatic context of the Thulean Province.

1. Pigeonite is a normal component of the groundmass of the basalts from the Middle and Upper Series of the Faeroe Islands (Jensen, 1978; Noe-Nygaard and Rasmussen, 1968), the general petrography of which seems closely similar to that of Leg 81 basalts. Pigeonite has also been described from some basalts of the Antrim area (Preston, 1982) in which several volcanic cy- cles have been recognized (Lyle, 1980), differentiation toward intermediate and acidic types occurring within each cycle (possible similarity with Hole 553A sequence).

2. Schilling and Noe-Nygaard (1974) have described an abrupt change from LREE-enriched to LREE-depleted patterns near the boundary of the Middle and Upper Series of the Faeroes Plateau Basalt. Although they have not found extremely low La contents such as those of Table 6, some of their data (La content close to 2 ppm: see Schilling and Noe-Nygaard's table 1) overlap with Leg 81 ones; they have attributed this change to a transition in magmatic regime from plume-derived to oceanic type.

3. Leg 81 basalts present the typical depleted extended Coryell-Masuda plots. As a whole, some trace-element characteristics of the British Tertiary Province basalts are similar to those of oceanic tholeites (Thompson, 1982). One of their major magma types, the Preshal Mhor basalt, is LREE depleted (Thompson et al., 1972; Esson et al., 1975; Mattey et al., 1977; Thompson et al., 1980 ), and its origin is attributed to a further limited partial fusion of a lherzolitic residue (resulting from the extraction of Skye Main Lava Series transitional basalt), leaving a final harzburgitic residue (Thompson et al., 1980). The Preshal Mhor and the Leg 81 basalts show relatively similar major-element compositions (high $\mathrm{CaO}$, very low $\mathrm{K}_{2} \mathrm{O}$ amounts), and in spite of many contrasts in their trace-element patterns (higher amounts of hygromagmaphile elements, $\mathrm{Nb}$ and $\mathrm{Rb}$ in Preshal Mhor basalts), they may perhaps be considered possible equivalents.

\section{REFERENCES}

Beckinsale, R. D., Brooks, C. K., and Rex, D. C., 1970. K-Ar ages for the Tertiary of East Greenland. Bull. Geol. Soc. Den., 20: 27-37.

Bertrand, H., Dostal, J., and Dupuy, C., 1982. Geochemistry of Early Mesozoic tholeiites from Morocco. Earth Planet. Sci. Lett., 58: 225-239.

Beziat, D. 1983. Etude pétrologique et géochimique des ophites des Pyrénées. Implications géodynamiques [Thèse de $3^{\circ}$ cycle] Universite de Toulouse.

Bizouard, H., Barberi, F., and Varet, J., 1980. Mineralogy and petrology of Erta Ale and Boina volcanic series, Afar Rift, Ethiopia. $J$. Petrol., 21:401-436.

Bougault, H., 1980. Contribution des éléments de transition à la compréhension de la genèse des basaltes océaniques. Analyse des éléments en traces dans les roches par spectrométrie de fluorescence $\mathrm{X}$ [Thesis] Université de Paris VI.

Bougault, H., Cambon, P., and Toalhouat, H., 1977. X-ray spectrometric analysis of trace elements in rocks. Correction for instrumental interferences. X-Ray Spectrom., 6(2):66-72.

Bougault, H., Cambon, P., Corre, O., Joron, J. L., and Treuil, M., 1979a. Evidence for variability of magmatic processes and upper mantle heterogeneity in the axial region of the Mid-Atlantic Ridge near $22^{\circ}$ and $36^{\circ} \mathrm{N}$. Tectonophysics. 55:11-34.

Bougault, H., Joron, J. L., and Treuil, M., 1979b. Alteration, fractional crystallization, partial melting, mantle properties from trace element in basalts recovered in the North Atlantic. In Talwani, M., Harrison C. G., and Hayes D. E. (Eds.), Deep Drilling Results in the Atlantic Ocean: Ocean Crust, Maurice Ewing Series, 2: 352-368.

Briqueu, L., Bougault, H., and Joron, J. L., 1983. Several geochemical characteristics common to magmatism associated with convergence zone: $\mathrm{Ta} / \mathrm{Nb}$ anomaly; petrogenetic implication (submitted to E.P.S.L.). 
Brown, G. M., 1982. Introduction to part 7 (the British Tertiary Province): An appraisal of the igneous history. In Sutherland, D.S. (Ed.), Igneous Rocks of the British Isles: New York (Wiley), 345-350.

Buddington, A. F., and Lindsley, D. H., 1964. Iron-titanium oxide minerals and synthetic equivalents. Petrol., 5:310-357.

Carmichael, I. S. E., 1967. The iron-titanium oxides of salic volcanic rocks and their associated ferromagnesian silicates. Contrib. Mineral. Petrol., 14:36-64.

Chayla, B. Jaffrezic, and H., Joron, J. L., 1973. Analyse par activation dans les neutrons épithermiques. Application à la détermination d'éléments en trace dans les roches. C. R. Hebd. Séances Acad. Sci. Ser. D, 277:273-275.

Coish, R. A., and Taylor, L. A., 1979. The effects of cooling rate on texture and pyroxene chemistry in D.S.D.P. Leg 34 basalt: A microprobe study. Earth Planet. Sci. Lett., 42:389-398.

De La Roche, H., and Govindaraju, K. 1976. Nouveaux étalons géochimiques: Granite GS-N et feldspath FK-N. Analusis. 4(8): 347-372.

Donnelly, T. W., Thompson, G., and Robinson, P. T., 1979. Very lowtemperature hydrothermal alteration of the oceanic crust and the problem of fluxes of potassium and magnesium. In Talwani M., Harrison C. G., and Hayes D. E. (Eds.), Deep Drilling Results in the Atlantic Ocean: Ocean Crust: Maurice Ewing Series, 2:383-390.

Esson, J., Dunham, A. C., and Thompson, R. N., 1975. Low alkali, high calcium olivine tholeiite lavas from the Isle of Skye, Scotland. J. Petrol., 16:488-497.

Etoubleau, J., Corre, O., Joron, J. L., Bougault, H., and Treuil, M., 1983 in press. Costa Rica Rift: Variably depleted basalts in the same hole. In Cann, J. R., Langseth, M. G., Honnorez, J., Von Herzen, R. P., White, S. M., et al., Init. Repts. DSDP, 69: Washington (U.S. Govt. Printing Office), 765-774.

Gamble, R. P., and Taylor, L. A., 1980. Crystal/liquid partitioning in augite: Effects of cooling rate. Earth Planet. Sci. Lett., 47:21-33.

Govindaraju, K., 1980. Report (1980) on three GIT-IWG rock reference samples: Anorthosite from Greenland, AN-G; Basalte d'Essey-le-Côte, BE-N; Granite de Beauvoir, MA-N. Geostandards Newletter. 4(1):49-138.

Jaffrezic, H. Joron, J. L., Treuil, M., and Wood, D. A., 1980. A study of the precision attained by neutron activation analysis using international standard rocks GS-N and BCR-I as examples. A discussion of a geochemical model accounting for the estimated errors. J. Radioanal. Chem. 55(2):417-425.

Jensen, A., 1978. Compositional variations of the pyroxenes from three flows of Faeroe Islands basalts. Bull. Geol. Soc. Den., 27: 37-63.

Joron, J. L., Bougault, H., Wood, D. A., and Treuil, M., 1978. Application de la géochimie des éléments en traces à l'étude des propriétés et des processus de genèse de la croûte océanique et du manteau supérieur. Bull. Soc. Géol. Fr., 20(7):521-531.

Joron, J. L., and Treuil, M., 1977. Utilisation des propiétés des éléments fortement hygromagmatophiles pour l'étude de la composition chimique et de l'hététogénéité du manteau. Bull. Soc. Géol. Fr., 19(7):1197-1205.

Kharbouch, F., 1982. Pétrographie et géochimie des laves dinantiennes de la Meseta nord-occidentale et nord-orientale marocaine. [Thèse de $3^{\circ}$ cycle] Université de Strasbourg.

Leeman, W. P., and Scheidegger, K. F., 1977. Olivine/liquid distribution coefficients as a test for crystal-liquid equilibrium. Earth Planet. Sci. Lett., 35:247-257.
Lyle, P., 1980. A petrological and geochemical study of the Tertiary basaltic rocks of Northeastern Ireland. J. Earth Sci., Roy. Dublin Soc., 2:137-152.

Mattey, D. P., Gibson, I. L., Marriner, G. F., and Thompson, R. N., 1977. The diagnostic chemistry, relative abundances, and spatial distribution of high-calcium, low-alkali olivine tholeiites dykes in the Lower Tertiary regional swarm of the Isle of Skye, N.W. Scotland. Mineral. Mag., 41:273-286.

Maury, R. C., Bellon, H., Bougault, H., Joron, J. L., Bohn, M., and de Graciansky, P. C., in press. Oceanic tholeites from the Celtic Sea passive margin, NE Atlantic: Geochemistry and mineralogy. In de Graciansky, P. C., Poag, C. W., et al., Init. Repts. DSDP, 80: Washington (U.S. Govt. Printing Office).

Noe-Nygaard, A., and Rasmussen, J., 1968. Petrology of a 3000 metre sequence of basaltic lavas in the Faeroe Islands. Lithos, 1:286-304.

Philpotts, J. A., and Schnetzler, C., 1968. Genesis of continental diabases and oceanic tholeites considered in light of rare-earth and barium abundances and partition coefficients. In Ahrens, L. H. (Ed.), Origin and Distribution of the Elements: Pergamon Press, 939-947.

Powell, R., and Powell, M., 1977. Geothermometry and oxygen barometry using coexisting iron-titanium oxides: a reappraisal. Mineral. Mag., 41:257-264.

Preston, J., 1982. The British Tertiary Province: Extrusive Rocks (Pt. 7). In Sabine R. A., Sutherland D. S., et al., Appendix A: Petrography of British Igneous rocks. In Sutherland, D. S. (Ed.), Igneous Rocks of the British Isles: New York (Wiley), 528-532.

Ragland, P. C., Brumfelt, A. O., and Weigand, P. W., 1971. Rare earth abundance in Mesozoïc dolerite dikes from Eastern United States. In Brumfelt, A. O., and Steinnes, E. (Eds.), Activation Analysis in Geochemistry and Cosmochemistry: (Universitets forlaget), 277-235.

Roberts, D. G., 1970. Recent geophysical investigations on the Rockall Plateau and adjacent areas. Proc. Geol. Soc. London, 1662:87-93.

, 1971. New geophysical evidence on the origins of Rockall Plateau and Trough. Deep-Sea Res., 18:353-359.

Schilling, J. G., and Noe-Nygaard, A., 1974. Faeroe-Iceland Plume: Rare-earth evidence. Earth Planet. Sci. Lett., 24:1-14.

Thompson, R. N., 1982. Geochemistry and magma genesis (Part 7: The British Tertiary Province). In Sutherland, D. S. (Ed.), Igneous Rocks of the British Isles: New York (Wiley), 461-477.

Thompson, R. N., Esson, J., and Dunham, A. C., 1972. Major element chemical variation in the Eocene lavas of the Isle of Skye, Scotland. J. Petrol, 13:219-254.

Thompson, R. N., Gibson, I. L., Marriner, G. F., Mattey, D. P., and Morrison, M. A., 1980. Trace element evidence of multistage mantle fusion and polybaric fractional crystallization in the Palaeocene lavas of Skye, NW Scotland. J. Petrol., 21:265-294.

Weigand, P. W., and Ragland, P. C., 1970. Geochemistry of Mesozoïc dolerite dikes from eastern North America. Contrib. Mineral. Petrol., 29:15-32.

Wood, D. A., Varet, J., Bougault, H., Corre, O. Joron, J. L., Treuil, M., Bizouard, H., Norry, M. U., Hawkesworth, C. J., and Roddick, J. C., 1979. The petrology, geochemistry and mineralogy of North-Atlantic basalts: A discussion based on IPOD Leg 49. In Luyendyck, B. P., Cann, J. R., et al., Init. Repts. DSDP, 49, Washington (U.S. Govt. Printing Office), 597-655.

Date of Acceptance: October 17, 1983 